\title{
Faculty Research Incentives and Business School Health: A New Perspective from and for Marketing ${ }^{\dagger}$
}

\author{
Stefan Stremersch* \\ Russell S. Winer** \\ Nuno Camacho***
}

November $14^{\text {th }}, 2020$

* Chair of Marketing and Desiderius Erasmus Distinguished Chair of Economics, Erasmus School of Economics, Erasmus University Rotterdam, the Netherlands, and Professor of Marketing, IESE Business School, Universidad de Navarra, Spain. Email: stremersch@ese.eur.nl

** William Joyce Professor of Marketing, Stern School of Business, New York University. Email: rwiner@stern.nyu.edu.

*** Associate Professor of Marketing, Erasmus School of Economics, Erasmus University Rotterdam, the Netherlands. Email: camacho@ese.eur.nl

* Corresponding author. Tel.: +31.10.4088719; Fax: +31.10.4089169. Address: Burg. Oudlaan 50, room E02-04, 3062 PA Rotterdam, the Netherlands.

$\dagger$ The authors acknowledge the comments provided by Vijay Hariharan, Eitan Muller, John Roberts, Roland Rust, Rick Staelin, Jan-Benedict Steenkamp, and Julian Villanueva. The usual disclaimer applies. This version was submitted to Journal of Marketing in November 2020 and is currently under review. 


\title{
Faculty Research Incentives and Business School Health: A New Perspective from and for Marketing
}

\begin{abstract}
Grounded in sociological agency theory, the authors study the role of the faculty research incentive system in the academic research conducted at business schools and business school health. The authors surveyed 234 marketing professors and completed 22 interviews with 14 (associate) deans and 8 external institution stakeholders. They find that research quantity contributes to the research health of the school, but not to other aspects of business school health. $r$-quality of research (i.e., rigor) contributes more strongly to the research health of the school than research quantity. $q$-quality (i.e., practical importance) of research does not contribute to the research health of the school but contributes positively to teaching health and several other dimensions of business school health. Faculty research incentives are misaligned: (1) when monitoring research faculty, the number of publications receives too much weight, while creativity, literacy, relevance, and awards receive too little weight; and (2) on average, faculty feels that they are insufficiently compensated for their research, while (associate) deans feel they are compensated too much for their research. These incentive misalignments are largest in schools that perform the worst on research $(r$ - and $q$-) quality. The authors explore how business schools and faculty can remedy these misalignments.
\end{abstract}

Keywords: business schools, marketing, academic research, research faculty, incentives, scientometrics. 


\section{INTRODUCTION}

Today's business schools consider academic research by their faculty as one of the main pillars in their business model and allocate a large part of their resources to it (e.g., faculty time, labs, research budgets). At the same time, prior research across fields, including the marketing field, has heavily debated whether the academic research that business school professors conduct adds value to the business schools that employ them (see Table $1^{1}$ ).

On the positive side, academic research may enhance a professor's relevant knowledge base, which can be transferred to students and motivate students to study the subject (Mitra and Golder 2008). Academic research may also signal teaching quality to high-quality prospective students (Besancenot, Faria and Vranceanu 2009). Business school faculty or deans may advocate certain schools based on their academic research performance thus affecting school choices and driving high-quality students and faculty to research-intensive schools (Mitra and Golder 2008).

On the negative side, scholars have voiced concerns that academic research in business schools does not live up to its full promise. For instance, many scholars have lamented the lack of practical importance of business school research (e.g., Jaworski 2011; Lilien 2011; Roberts, Kayande and Stremersch 2014) in favor of excessive sophistication (Benbasat and Zmud 1999; Lehmann, McAlister and Staelin 2011). At the same time, some particularly notorious science fraud cases have arisen in business school research calling into question the integrity of academic research in management (Bettis 2012; RRBM 2017).

\footnotetext{
${ }^{1}$ Table 1 lists the most prominent articles that have appeared in the journals indexed by the UT Dallas Research Ranking (https://jindal.utdallas.edu/the-utd-top-100-business-school-research-rankings/) that covered the role of faculty research in business schools. Note it does not include articles focusing almost exclusively on scientometric properties of research (so-called scientometric studies), such as for example Stremersch, Verniers, and Verhoef (2007), or Stremersch et al. (2015).
} 
Prior literature has hinted that the faculty research incentive system of business schools, composed of monitoring and compensation instruments, may be responsible for the main concerns on rigor (formally, $r$-quality) and practical importance (formally, $q$-quality) that are voiced about business school research (Lehmann, McAlister and Staelin 2011; Lilien 2011; Reibstein, Day and Wind 2009; Vermeulen 2005). The purpose of this article is to examine the effects of the faculty research incentive system on the execution of the research task by faculty, and thereby, on a holistic set of business school outcomes which, following prior work in the educational literature (e.g., Hoy and Woolfolk 1993), we conceptualize as "business school health". Business school health, developed more elaborately below, is the extent to which a business school prospers in the long term, for which it must perform well (1) at the technical level (i.e., research and teaching), (2) at the institutional level (i.e., external support and institutional integrity), and (3) at the managerial level (i.e., leadership support, administrative support, and resource support). We define all key terms in Table 2.

This paper offers three contributions to prior literature. First, prior papers often are purely conceptual. The present paper is grounded in theory and presents empirical evidence. Second, many papers take a scholarly field perspective rather than a business school perspective. Exceptions (Bennis and O'Toole 2005; Mitra and Golder 2008; Pfeffer and Fong 2002; Trieschmann et al. 2000) focus on specific business school outcomes (e.g., MBA ranking) or specific research metrics (e.g., number of publications) and often contradict each other with some being very negative and others being more positive. This paper also takes a business school perspective, but offers more elaboration on faculty research incentives, faculty research task, and business school outcomes (i.e., business school health) than prior research. Third, prior work that has suggested that the faculty research incentive system is one of the main culprits for today's state 
of affairs (e.g., see Lilien 2011; Reibstein, Day, and Wind 2009; Vermeulen 2005) did not theoretically conceptualize this faculty research incentive system or offer empirical evidence of its misalignment. This paper does both. It develops a new model for the faculty research incentive system grounded in sociological agency theory and offers empirical evidence of its misalignment.

We theoretically ground our conceptual framework in sociological agency theory (Shapiro 2005), applied to the role of academic research in business schools, the latter of which developed organically as a field of inquiry (see Table 1). We test the hypotheses we develop in (1) a survey of 234 marketing professors of business schools across 20 countries (response rate of 62.6\%); (2) complemented by 22 qualitative interviews with 14 (associate) deans of 13 business schools in the U.S. and Europe, and 8 external stakeholders, including leaders of five external institutions of marketing scholarship (e.g., the American Marketing Association and the Marketing Science Institute), and senior marketing practitioners at three large multinational firms.

Our main conclusions are as follows. Regarding the faculty research incentive system, we find that, on average, research task incentives are badly designed. Among monitoring instruments, we find that number of publications receives too much weight in faculty evaluations while creativity, literacy, relevance to non-academics, and awards (in order of importance) receive too little weight. Among compensation instruments, we find a misalignment in that faculty overall feel they are insufficiently compensated while (associate) deans feel faculty are compensated too much for their research. We find that badly designed incentive systems are more prevalent in schools that perform below-median on research quality, i.e., $r$-quality (i.e., rigor) and $q$-quality (i.e., practical importance). We do not find such a relationship between badly designed research incentives and research quantity. 
Regarding the research task of faculty, we find that research quantity contributes to research health but not to other aspects of business school health. $r$-quality of research contributes more strongly to research health than research quantity and $q$-quality of research. q-quality of research does not contribute to research health, but contributes positively to teaching health, as well as several other dimensions of business school health, such as external support (by alumni and donors), and institutional integrity.

Our findings have important implications for business schools and for research faculty. First, when monitoring research faculty, business schools should find a better balance between low-effort metrics (e.g., number of publications or citations) and effortful metrics (e.g., creativity and literacy). Second, in terms of compensation, business schools should better align faculty with the mission of the school rather than their own self-interest. One way to do so is to give faculty a better understanding of the entire organization, its operations, and its finances. Third, business schools should steer their research audits to more effectively stimulate the $r$-quality and/or the $q$ quality of their faculty's research. Fourth, our findings also suggest that business schools' research faculty should work on increasing $q$-quality without decreasing $r$-quality of their work.

\section{FACULTY RESEARCH IN BUSINESS SCHOOLS:}

\section{A SOCIOLOGICAL AGENCY FRAMEWORK}

To conceptualize faculty research in business schools, we develop a sociological agency framework. In this framework, we distinguish four elements: (1) constituents (e.g., principal, agents, and institutions), (2) incentive instruments ${ }^{2}$ the principal uses to motivate the agent (e.g., publication metrics), (3) the task of the agent (e.g., research), and (4) desirable outcomes for the principal (e.g., business school health). Figure 1 depicts our sociological principal-agent

\footnotetext{
${ }^{2}$ For brevity, in our theorizing we refer to the "faculty research incentive system" as "incentive instruments." We treat both terms as synonyms (see also Table 2 ).
} 
framework, showcasing the different constituents in our framework. Figure 2 depicts the effects we empirically examine in this paper, namely, the effect of the faculty research incentive system on the research task of faculty, and of the latter on business school health.

\section{Constituents: Principal, Agents, and Institutions}

The principal in our framework is the business school as a "collective principal" (e.g., Nielson and Tierney 2003). Business schools typically operate within a university which oversees the school's incentive system (exceptions exist, e.g., INSEAD) and are divided into disciplinary units or departments each of which influences the school's incentive system (see top of Figure 1). The agent in our framework is a research or tenure-track faculty member. The business school incentivizes agents by monitoring and compensating the faculty member's research task.

External institutions are organizations outside the governance of the business school that play an essential role in social monitoring because principal-agent relationships are "enacted in a broader social context and buffeted by outside forces" (Shapiro 2005; p. 269) ${ }^{3}$. Building on Ahuja and Yayavaram (2011), we discern two external institutions of special relevance ${ }^{4}$ : (i) endorsement institutions, and (ii) cohesion institutions (see the bottom of Figure 1; for a primer and nonexhaustive list of these institutions with relevance to the marketing field, see section W1 in the Web Appendix).

Endorsement institutions verify information about agents, conduct analyses to compare or rank agents, and endorse agents. Examples of such institutions in marketing that endorse faculty

\footnotetext{
${ }^{3}$ Social monitoring may occur when the business school appeals to external institutions (e.g., by considering whether the agent received or has been a finalist in external institutions' awards) to monitor agents. Social monitoring may also occur when the business school appeals to peers of the agent at other business schools (e.g., to write reference letters for faculty promotion), or to peers of senior administrators (e.g., when deans evaluate each other in business school rankings and AACSB reviews). We represent such social monitoring with two left-right arrows in the center of Figure 1.

${ }^{4}$ Ahuja and Yayavaram (2011) raise three other types of institutions that are responses to market failure issues (e.g., power asymmetry and agreement consummation) which have not been connected to principal-agent theory and do not seem relevant in our context.
} 
are premier journals that publish their research (such as Journal of Marketing) or associations

(such as the AMA) that have a variety of awards for research. Cohesion institutions ensure collective action by enabling the provision of collective goods. For example, collaborative research platforms, such as MSI and professional associations such as the AMA are good examples of such cohesion institutions (note that institutions can provide endorsement as well as cohesion as is the case for the AMA).

\section{Incentives: Monitoring and Compensation Instruments ${ }^{5}$}

Monitoring instruments are the devices that principals use to measure an agent's effort or outcomes (Joseph and Thevaranjan 1998). We identified the following seven monitoring instruments relevant for business schools (e.g., Aguinis et al. 2020; Lightfield 1971): (1) number of publications, (2) number of citations, (3) peer recognition, (4) awards, (5) relevance to nonacademics, (6) literacy ${ }^{6}$, and (7) creativity.

Compensation instruments are the rewards, pecuniary and non-pecuniary, that principals use to align the actions of agents with their own objectives (Pepper and Gore 2015). We identified the following seven compensation instruments used by business schools (e.g., Gomez-Mejia and Balkin 1992): (1) salary, (2) performance-based salary increases, (3) publication bonuses paid as salary supplements ${ }^{7},(4)$ research budgets, (5) publication bonuses paid as supplementary research budget $^{8},(6)$ academic freedom, and (7) reduced teaching loads.

\footnotetext{
${ }^{5}$ We focus solely on business schools' research incentives and how they incentivize agents' research task. Therefore, we do not examine incentives for other tasks of these agents (e.g., the teaching task).

${ }^{6}$ By literacy we mean how 'well-read' a scholar is, in line with the American Library Association (2000) definition of "information literacy" which is a person's ability to "locate, evaluate, and use effectively the needed information" (p.2). We provided this definition also in our faculty survey to avoid confusion over the meaning of this term.

${ }^{7}$ The distinction between performance-based salary increases and publication bonuses is important because the former are typically permanent compensation increases, whereas the latter are one-time compensation increases and thus may have different effects on agents' behavior (e.g., Clotfelter et al. 2008).

${ }^{8}$ The distinction between publication bonuses paid as salary supplements versus paid as supplementary research budget is important because it taps into the classic distinction, in the agency literature, between pecuniary and non-
} 


\section{Task: Faculty Research}

The research task of faculty in business schools is to produce research of sufficient quantity ("doing enough research") and quality ("doing research that is good enough") to achieve the ambitions of a healthy school. Research quantity relates to the total volume of research produced by a scholar (e.g., Lightfield 1971). For research quality, we distinguish " $r$-quality" from " $q$ quality" (Ellison 2002). Academic research is of high $r$-quality (i.e., rigorous) if it adheres to “objective, scientific standards" (Bennis and O’Toole 2005; p. 99), which means that "the various elements of a theory are consistent, that potential propositions or hypotheses are logically derived, that data collection is unbiased, measures are representative and reliable, and so on" (Vermeulen 2007; p. 755). Academic research is of high $q$-quality (i.e., practically important) if it provides insights that "practitioners find useful for understanding their own organizations and situations better than before" (Vermeulen 2007; p. 755).

\section{Outcome: Business School Health}

The health metaphor was initially applied to schools by Miles (1965). Following the classic work of Parsons (1951) and Hoy (Hoy, Tarter and Kottkamp 1991; Hoy and Woolfolk 1993), we conceptualize business school health as the extent to which a business school prospers in the longterm, for which it must perform well (1) at the technical level, (2) at the institutional level, and (3) at the managerial level. At the technical level, a business school should have high research health (i.e., research faculty are seen as leading in their respective fields, publish regularly in leading journals, and assume academic leadership positions), and high teaching health (i.e., the school offers an excellent learning environment with high standards for teaching). At the institutional

pecuniary rewards (e.g., Pepper and Gore 2015). Specifically, even though publications bonuses paid as supplementary research budget are monetary in nature, the benefits that a research faculty member derives from such bonuses are non-pecuniary (e.g., easier access to data and equipment, higher travel allowances to visit conferences, etc.) 
level, a business school should have high external support (i.e., very good relationships with alumni and donors, who commit substantial resources to the school), and high institutional integrity (i.e., faculty and students uphold the highest standards of integrity). At the managerial level, a business school should have strong leadership support (i.e., a high quality leadership team and clear faculty performance standards), strong administrative support (i.e., professional administrative staff that is supportive to faculty, students and visitors), and strong resource support (i.e., adequate facilities and resources to help faculty effectively perform their work).

\section{HYPOTHESES DEVELOPMENT}

We now develop our hypotheses starting with the effects of incentive instruments on the research task of faculty ${ }^{9}$.

\section{Incentive Instruments and the Research Task of Faculty}

Business schools design incentive instruments to motivate research faculty to do enough research that is good enough. According to classical agency theory (e.g., Holmstrom and Milgrom 1991), incentive instruments increase an agent's motivation by raising the marginal cost of bad performance (through monitoring) and/or the marginal reward of good performance (through compensation). Higher motivation, in turn, leads the agent to work harder and to perform better on her or his task. However, there are multiple reasons to expect the effect of incentive instruments on the research task of professors in business schools to be more nuanced.

Incentive instruments may be improperly weighted and deviate from what agents, but also principals, see as the optimal incentive system. Improperly weighted incentive instruments may arise in business schools for several reasons. First, optimal incentives may be very costly to implement (Joseph and Thevaranjan 1998; Roberts 2010). For instance, output quality is more

\footnotetext{
${ }^{9}$ Note that all hypotheses are formulated "ceteris paribus."
} 
expensive to monitor than output volume (Holmstrom and Milgrom 1991). Second, (associate) deans may not always be well-informed (befitting Sharma's (1997) argument in the context of professional services), because they may not have a strong research record themselves or have been detached from research activities themselves for a long time. Third, (associate) deans may also be biased and design incentive instruments to benefit the school's present faculty and their present behaviors rather than to steer towards a desired behavior. This happens because (associate) deans often arise from the same collegial ranks as a "primus inter pares" and, after their role as (associate) dean, typically return to their "regular" faculty positions.

Improperly weighted incentive instruments may deteriorate the research task execution of faculty in business schools for two main reasons. First, prior research has established that badly designed incentive systems reduce the intrinsic motivation of the agent (Frey and Jegen 2001). According to Frey and Jegen (2001), agents in badly designed incentive systems may feel underappreciated (e.g., "my competence or involvement is not properly acknowledged"), which impairs self-esteem, or agents may feel externally pressured (e.g., "I need to publish x number of papers to get tenure"), which impairs self-determination.

Impaired self-esteem reduces agents' persistence in the face of setbacks (McFarlin, Baumeister and Blascovich 1984). Persisting through setbacks is, however, critical to "survive" a peer review process geared towards improving r-quality (Akerlof 2020; Ellison 2002), Thus, impaired self-esteem may lead scholars to sacrifice $r$-quality.

Impaired self-determination reduces creativity (Amabile 1998), which is an important precursor to q-quality (Stewart 2020). For instance, Bradlow (2008) argues that home run papers "pose new questions that we had never thought to ask" or "allow us to see existing problems and 
solutions from a new perspective" (p. 5). Along similar lines, Shugan (2003) argues that creativity leads to better and more applicable predictions and theories.

Second, as it is less expensive to monitor quantity than quality, badly designed incentive systems may lead business schools to incentivize quantity more strongly than quality. For example, an increasing number of automated scientometric tools may lead principals to overweight metrics such as number of publications. Overweighting quantity, in turn, may lead faculty to become extrinsically motivated to publish as many papers as possible, possibly leading them to ignore quality (Holmstrom and Milgrom 1991), or to engage in undesirable practices to game the metrics rather than optimize the task itself (Roberts 2010). An example is "salami publishing" (i.e., trying to squeeze as many papers as possible out of a research project; Heckman and Moktan 2020; p. 462). Therefore, we hypothesize:

H1: In business schools with improperly weighted incentive instruments, research faculty (a) produces research of lower r-quality, (b) produces research of lower q-quality, and (c) produces a higher quantity of research, all compared to business schools with properly weighted incentive instruments.

\section{The Research Task of Faculty and Business School Health}

We now postulate the effects of the research task of faculty on research health and teaching health as well as on external support and institutional integrity. For the managerial level of business school health (i.e., leadership support, administrative support, and resource support) - as it exists to facilitate organizational goals at the technical and institutional levels - we do not develop exante expectations ${ }^{10}$.

\footnotetext{
${ }^{10} \mathrm{We}$ develop our theorizing at the level of these seven dimensions rather than at the overall business school health level. We do so for two reasons. First, the seven dimensions we identified are non-compensatory. A high performance in one dimension does not necessarily compensate for a low performance in another dimension (e.g., increases in teaching health do not necessarily compensate for a low research health, and vice versa). Second, the antecedents we study may have different effects on the different dimensions. Note that this does not mean that business school health is a formative construct. Instead, we treat business school health as a superordinate label and the seven subordinate dimensions as facets that collectively define it (Cohen et al. 1990; Edwards 2011).
} 
The research task of faculty and research health of the business school

Scholars who publish a high research quantity (controlling for quality) have higher visibility than scholars who publish a low research quantity (Stremersch, Verniers, and Verhoef 2007). Scholars who frequently "survive" peer review also demonstrate to others they know "what is needed, correct, and valued" by the research system (Lehmann, McAlister and Staelin 2011; p. 156), and typically attract more collaborations (Franceschet 2011), increasing their belongingness in the academic community. Higher visibility and belongingness, in turn, increase the odds that a scholar is seen as a leader in the field and assumes academic leadership positions. Therefore, we hypothesize that:

H2: The research health of a business school increases with the production of higher quantity of research by its research faculty.

For research quality, the effect on research health may be more nuanced; we expect increases in $r$-quality of faculty's research to contribute more strongly to research health of a business school than increases in q-quality of faculty's research. Agarwal and Ohyama (2013) show that scholars acclaim stronger reputational rewards to basic than to applied science because basic research requires a higher level of scientific ability than applied science. Basic research is typically higher in rigor than applied research, which, in turn, is typically higher in practical importance (Tushman and O'Reilly 2007). Akerlof (2020) calls this the "hardness bias", which he also attributes to the greater agreement among scholars on $r$-quality than on $q$-quality. In turn, the greater reputational rewards faculty may derive from increments in $r$-quality, as compared to increments in $q$-quality, fuel opportunities to take up leadership roles in journals and in the academic research community (Ellison 2002), which, in turn, positively impacts the research health of the school. Therefore, 
H3: The research health of a business school increases more as research faculty produces research of higher r-quality, than as research faculty produces research of higher q-quality.

The research task of faculty and teaching health of the business school

Research quantity may have two opposite effects on teaching health. On the one hand, a high volume of research may give faculty members a broader knowledge base in their teaching subjects, increasing their ability to set high teaching standards and to motivate students' interest in the subject (Mitra and Golder 2008). On the other hand, research and teaching activities compete for faculty time. Assuming a time constraint, the more research faculty allocates time to writing papers, the less they allocate time to preparing classes, teaching materials and meeting students. Besancenot, Faria, and Vranceanu (2009) analytically show that increasing research output may deteriorate teaching quality. Given these conflicting views, we formulate two alternative hypotheses for empirical testing:

H4a: The teaching health of a business school increases as research faculty produces a higher quantity of research.

H4b: The teaching health of a business school decreases as research faculty produces a higher quantity of research.

Faculty members who produce research high in $q$-quality typically immerse themselves in real-world managerial practice through consulting, case writing, or executive education (Vermeulen 2007). Such immersion, in turn, increases a faculty member's proximity to managerial practice and their usage of concrete concepts (e.g., "cellular phone"), which are easier to contextualize and understand than abstract concepts (e.g., "communication device"; Trope and Liberman 2010). Moreover, given their greater proximity to managerial concepts and practical cases, faculty who produce high $q$-quality research are more likely to share personal experiences with real-world cases in class which are more vivid and memorable (Simonsohn et al. 2008), thereby increasing student engagement. 
In contrast, faculty members who produce research high in $r$-quality use rigorous conceptual thinking and empirical methods to discover generalizable principles (Daft and Lewin 1990; MacInnis 2011). To discover generalizable principles, high $r$-quality faculty tend to adopt abstract concepts, because abstraction allows them to focus on the central and enduring features of an object while screening out contextual details (Trope and Liberman 2010). Moreover, their strong theoretical and methodological grounding leads them to underestimate that such abstract concepts may not be obvious to less informed audiences (Thaler 2000), possibly leading them to use such abstract concepts when teaching students. Prior literature shows that teaching in abstract rather than concrete language reduces student comprehension and memory retention (Sadoski, Goetz, and Fritz 1993). Hence, we hypothesize:

H5: The teaching health of a business school increases more as research faculty produces research of higher q-quality, than as research faculty produces research of higher r-quality.

Note that while faculty members may excel both in $r$-quality and in $q$-quality, such "dual excellence" profiles may be rare. Specifically, as we argued above, most scholars face time constraints which means that the activities required to increase one's $r$-quality (e.g., staying abreast of the latest scientific advances) may compete for faculty time with the activities required to increase one's q-quality (e.g., immersing oneself in managerial practice). Hattie and Marsh (1996) use a similar logic to argue that time constraints make it hard for most scholars to excel simultaneously in research and in teaching, as either of the two activities is labor-intensive.

The research task of faculty and external support to the business school

We expect increases in research quantity to contribute less to external sponsors' (i.e., alumni and donors) willingness to donate their time or money to the school than increases in research ( $r$ - and $q$-) quality. Using self-reported data from alumni, Mael and Ashforth (1992) show that donors' self-esteem increases more when they donate to a high prestige than to a low prestige 
school. The prestige of an academic institution, in turn, is typically earned mainly through the production of high-quality research (Armstrong and Sperry 1994). This happens for two reasons.

First, in adverse environments, a rare favorable outcome (e.g., publishing a "home run" paper) conveys more information about an individual's ability than being able to achieve several less favorable outcomes (Shugan and Mitra 2009). Thus, research quality is more significant than research quantity in eliciting recognition through awards, appointments to prestigious academic departments and overall prestige among national and international peers (Cole and Cole 1967).

Second, the awards and accolades bestowed to high-quality scholars serve as signals of appreciation and recognition by external experts (Frey and Gallus 2017). Mael and Ashforth (1992) argue that academic institutions can symbolically manage such signals as 'identity anchors' that increase the salience of the institution among alumni and donors and, ultimately, their willingness to support the institution. Accordingly, we argue that increments in ( $r$-and $q$-) quality have a stronger positive effect on a business school's external support than increments in research quantity, ceteris paribus:

H6: The external support for a business school increases more as research faculty produces research of higher quality (in both $r$ - and q-quality) than as research faculty produces a higher quantity of research.

The research task of faculty and institutional integrity of the business school

We expect increases in $r$-quality to contribute positively to a business school's institutional integrity. Specifically, scholars that foster high $r$-quality research continuously dialogue with high $r$-quality peers to remain abreast of the latest scientific ethics codes and guidelines, which typically promote transparency, integrity, and reproducibility (Nosek et al. 2015; RRBM 2017). The continuous engagement of high $r$-quality scholars in peer networks that promote research integrity helps their business schools commit to the highest standards of integrity for two reasons. 
First, high $r$-quality scholars help disseminate high integrity research practices to peers, for instance by raising other scholars' awareness about questionable research practices (e.g., John, Loewenstein, and Prelec 2012), or by formally or informally persuading young faculty and doctoral students to uphold the norms and practices that comprise "good science" (Bedeian, Taylor and Miller 2010).

Second, internalizing high standards of integrity helps strengthen a person's "moral muscle" (Baumeister and Exline 1999), which may, in turn, promote the dissemination of high ethical values to students. For instance, prior research argues that research faculty are better able than non-research faculty to teach the process of knowledge discovery to their students (Mitra and Golder 2008). Extending this argument, we expect research faculty high in $r$-quality to be better able than research faculty low in $r$-quality of teaching their students how to commit to the highest standards of integrity in their academic work, thereby improving the communication of strong ethical values in the classroom. Therefore:

H7: The institutional integrity of a business school increases as research faculty produces research of higher r-quality.

We do not have theoretical expectations regarding the effects of research quantity and $q$ quality on a business school's institutional integrity. We explore such effects empirically. Other effects

In $\mathrm{H} 2$ to $\mathrm{H} 7$, we stipulate our hypotheses for the effects of the research task of faculty on research health and teaching health (i.e., the technical level), as well as external support and institutional integrity (i.e., the institutional level), of a business school. Even though we do not develop ex ante expectations for the managerial dimensions of business school health, we explore such effects in the empirical section of the paper. Our conceptualization of the faculty research incentive system implies that feedback loops may exist in two main ways (see right-to-left arrows 
at the bottom of Figure 2): (1) business school health may influence the faculty in the execution of their research task; and (2) business school health may lead to adjustments in monitoring and compensation. While our empirical context does not allow us to separately identify these feedback loops, we allow for correlated error terms to accommodate possible co-variation across business school health dimensions introduced by these reciprocal linkages.

\section{EMPIRICAL STUDIES}

In this section, we examine whether there is empirical support for our hypotheses by surveying a large number of marketing faculty members at business schools and by interviewing a concise sample of (associate) deans of business schools and external stakeholders.

\section{Study 1: A Large-Scale Survey of Marketing Research Faculty at Business Schools}

Data collection. We invited 374 marketing academics across 168 business schools to respond to our survey; 234 responded $(62.6 \%)$; $182(77.8 \%)$ respondents work at researchintensive schools (i.e., schools where tenure criteria are mainly research focused); 149 of the respondents $(63.7 \%)$ work at business schools that are ranked in the Top 100 FT Global MBA ranking. Further details on the survey sampling, as well as questionnaire structure, analysis and results appear in the Web Appendix (section W2; survey data are available at www.frisbuss.com $\left.{ }^{11}\right)$.

Measurement. Regarding the faculty research incentive system, we asked respondents if, at their school, each of the seven monitoring instruments we study receives far too little weight (2), too little weight $(-1)$, just the right weight (0), too much weight $(+1)$, or far too much weight $(+2)$. With regard to compensation, we asked respondents whether they felt research faculty at

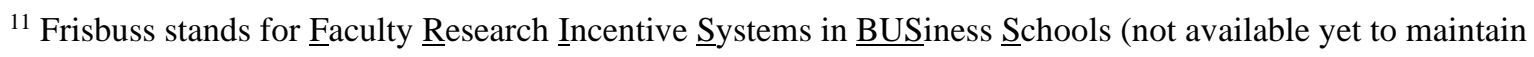
double-blind review process).
} 
their school receive far too little (-2), too little (-1), just the right level $(0)$, too much $(+1)$ or far too much (+2) of each of the seven compensation instruments we study.

Regarding the research task of faculty, we asked respondents whether the performance of research faculty at their business school in each of the three dimensions of the research task (i.e., research quantity, $r$-quality, and $q$-quality of research) was "very low", "low", “moderate", "high" or "very high".

To measure business school health, we modified the items from Hoy, Tarter and Kottkamp (1991) to match the specific context of business schools. We used a total of 21 items (see Table 3 for a complete list of items). To test the underlying structure of the business school health scale, we conducted two types of factor analyses. First, we conducted a principal component analysis with varimax rotation on the full set of 21 items. The scree plot criterion suggested a seven-factor structure with all items loading on their expected theoretical dimensions ${ }^{12}$. The seven components accounted for $82.6 \%$ of the total variance with the largest component accounting for $12.7 \%$ of the total variance. All loadings were greater than the recommended threshold of .60 (Guadagnoli and Velicer 1988) with the lowest being .73 (see Table 3).

Second, we conducted a seven-factor confirmatory factor analysis (CFA). The CFA model had a chi-square of $251.08(p<.01)$ with 168 degrees of freedom. The fit indices for this model meet the recommended standards: Comparative Fit Index $(\mathrm{CFI})=.98$, Non-Normed Fit Index $(\mathrm{NNFI})=.97$, Root Mean Square Error of Approximation $(\mathrm{RMSEA})=.05$, and Standardized Root Mean Square Residual $(\mathrm{SRMR})=.04^{13}$.

\footnotetext{
12 The eigenvalue criterion suggested a six-component structure combining the items of leadership support and institutional integrity. However, the seventh component had an eigenvalue very close to 1 (.93) and confirmatory factor analyses (see below) showed that the seven-component solution fits the data better.

${ }^{13}$ We also ran a second-order factor model with a latent business school health factor as second-order construct and the seven dimension of business school health as the first-order constructs to investigate whether such a second-order factor existed. The second-order factor model had a worse fit than the first-order factor model according to all indices $(\mathrm{CFI}=.96, \mathrm{NNFI}=.96, \mathrm{RMSEA}=.06, \mathrm{SRMR}=.19)$.
} 
Overall, our business school health scale exhibits good psychometric properties. All seven dimensions show composite reliabilities above the recommended threshold of .70 (Bagozzi and Yi 1988), the smallest being .80 (see Table 3 ). All factor loadings were positive, highly significant (minimum z-value was 18.77; all $p$-values below 0.01 ), and at least ten times as large as the standard errors establishing convergent validity (Gerbing and Anderson 1988). We then used Fornell and Larcker's (1981) discriminant validity test to assess whether the different dimensions of business school health are clearly distinguishable. For all pairs of business school health dimensions, the square root of the average variance extracted for both dimensions was greater than their correlation, which suggests discriminant validity. We averaged respondents' answers to the items measuring each business school health dimension to produce seven summated scales as is standard in psychometrics (Hair et al. 2014).

Common method bias. We also addressed common method variance (CMV) bias. Ex ante, we (1) promised confidentiality to respondents (Podsakoff et al. 2003), (2) used well-defined response labels that varied across questions (Podsakoff et al. 2003; Rindfleisch et al. 2008), and (3) asked research faculty to evaluate their business school's performance rather than their own performance triggering high involvement and informant reliability (Homburg et al. 2012) while reducing social desirability (Engeler and Raghubir 2018). Ex post, we found that (1) the largest factor in our principal component analysis accounted for only $12.7 \%$ of the variance explained, and (2) a single-factor CFA model on the same construct fits the data worse than our hypothesized model $(\mathrm{CFI}=.49, \mathrm{NNFI}=.43, \mathrm{RMSEA}=.20, \mathrm{SRMR}=.12)$. Both findings are inconsistent with severe CMV.

Results: Incentive instruments and the research task of faculty. Figure 3 shows the average value $(\mu)$ for each incentive instrument with the asterisks depicting whether this value is 
significantly different from 0 ( 0 indicates that the weight given to that instrument is "just right") based on a t-test. We find that, on average, research faculty feel that business schools' research incentive systems are badly designed.

In terms of monitoring instruments (Figure 3; left panel), research faculty feel that, on average, the "number of publications" receives too much weight $(\mu=.39 ; \mathrm{t}=6.88 ; p<.01)$. All the remaining monitoring instruments - including number of citations - are significantly underweighted. The monitoring instruments most severely underweighted (in order) are: (1) creativity $(\mu=-.65 ; \mathrm{t}=-12.95 ; p<.01),(2)$ literacy $(\mu=-.49 ; \mathrm{t}=-10.05 ; p<.01)$, and (3) relevance to non-academics $(\mu=-.44 ; \mathrm{t}=-8.58 ; p<.01)$.

In terms of compensation instruments (Figure 3; right panel), we observe that, on average, research faculty feel insufficiently compensated except for the academic freedom they get. We also found that research faculty called out for an increase in their compensation especially in the form of (in order): (1) bonuses paid as research budget ( $\mu=-.84 ; \mathrm{t}=-10.34 ; p<.01)$; (2) bonuses paid as salary $(\mu=-.77 ; \mathrm{t}=-9.47 ; p<.01)$; and $(3)$ reduced teaching loads $(\mu=-.67 ; \mathrm{t}=-10.36 ; p<.01)$.

To test H1, we first generated a 2-by-2 matrix according to a median split on research quantity and $r$-quality (Figure 4; left panel). We classified respondents as below-median or abovemedian in terms of the performance on research quantity and $r$-quality of their business school. Then, for each respondent, we computed the Mean Absolute Deviation (MAD) from 0 aggregated across all seven monitoring $\left(\mathrm{MAD}^{\mathrm{M}}\right)$ and compensation $\left(\mathrm{MAD}^{\mathrm{C}}\right)$ instruments ${ }^{14}$. We then averaged the individual scores to obtain the average $\mathrm{MAD}^{\mathrm{M}}$ and $\mathrm{MAD}^{\mathrm{C}}$ for each of the cells in the 2-by-2 matrix.

\footnotetext{
${ }^{14}$ The mean absolute deviation is a proxy for the extent to which the respondent perceives the mix of incentive instruments at her business school as improperly weighted as it gives us the average absolute deviations from the midpoint of the scales indicating whether a given instrument receives the "right weight".
} 
We ran two one-way ANOVA analyses of the $\mathrm{MAD}^{\mathrm{M}}$ and $\mathrm{MAD}^{\mathrm{C}}$ by respondents across the four cells in the left panel of Figure 4. Fisher-Hayter post-hoc tests ${ }^{15}$ show that in schools with above-median $r$-quality (i.e., upper cells in the left panel of Figure 4), monitoring instruments are more properly weighted (i.e., lower $\mathrm{MAD}^{\mathrm{M}}$ ) than in schools with below-median $r$-quality (i.e., lower cells), an effect that is significant both at low levels of research quantity $(p<.05)$ and at high levels of research quantity $(p<.01)$. In terms of compensation, we also find that in schools with above-median $r$-quality (i.e., upper cells), compensation instruments are more properly weighted (i.e., lower $\mathrm{MAD}^{\mathrm{C}}$ ) than in schools with below-median $r$-quality (i.e., lower cells), an effect that is significant at the $10 \%$ level at low levels of research quantity $(p<.10)$ and approaches significance at high levels of research quantity $(p=.14)$. These results lend support to H1a. We do not find such a contrast for research quantity (i.e., the differences between the left cells and the right cells in the left panel of Figure 4 are not significant; see Web Appendix, section W2).

We used the same approach described above to generate a 2-by-2 matrix according to a median split on research quantity and $q$-quality (Figure 4; right panel). We then ran two one-way ANOVA analyses of the $\mathrm{MAD}^{\mathrm{M}}$ and $\mathrm{MAD}^{\mathrm{C}}$ by respondents across the four cells in the right panel of Figure 4. Consistent with H1b, Fisher-Hayter post-hoc analyses show that in schools with above-median $q$-quality (i.e., upper cells in the right panel of Figure 4), monitoring instruments are more properly weighted (i.e., lower $\mathrm{MAD}^{\mathrm{M}}$ ) than in schools with below-median $q$-quality (i.e., lower cells), an effect that is significant at low levels of research quantity $(p<.05)$, but not at high levels of research quantity $(p=.18)$. We do not find such a contrast for compensation instruments

\footnotetext{
${ }^{15}$ We use Fisher-Hayter's procedure because it has more power compared to other post-hoc comparison methods such as Tukey's test. Note that Fisher's LSD also has more power than Tukey's test, but it does not correct for multiple comparisons which may inflate Type I error (Williams and Abdi 2010). Fisher-Hayter's test is a revised version of the LSD test proposed by Hayter to overcome the weaknesses of the LSD test (Williams and Abdi 2010).
} 
$\left(\mathrm{MAD}^{\mathrm{C}}\right)$. We also do not find such a contrast for research quantity (Web Appendix, section W2), so we are not able to confirm H1c.

Results: The research task of faculty and business school health. To test $\mathrm{H} 2-\mathrm{H} 7$, we regressed the seven dimensions of business school health on the three dimensions of the research task (research quantity, $r$-quality and $q$-quality). We jointly estimate seven equations using a multivariate regression system where we allow the error terms to be correlated across equations (for the econometric specification, see Web Appendix, section W2). The Lagrange multiplier test proposed by Breusch and Pagan (1980) confirms that the covariance matrix between error terms is not diagonal $\left(\chi_{(21)}^{2}=573.8 ; p<.01\right)$. The fit of the model is satisfactory. The $R^{2}$-statistic is highest for research health (.46) which befits the prime focus of our investigation.

We depict our results in Table 4. The first four rows show the parameter estimates from our multivariate regression, whereas the subsequent seven rows show the residual correlations among the different business school health dimensions. Consistent with $\mathrm{H} 2$, we find that higher research quantity is associated with higher research health $(\beta=.28 ; p<.01)$. We also find that the higher the $r$-quality (i.e., rigor) of faculty research, the higher the research health of a business school $(\beta=.52 ; p<.01)$. In contrast, $q$-quality has no significant effect on research health $(\beta=.05$; $p=.32)$. A Wald test rejected the null hypothesis that both parameters are equal in size $(\mathrm{F}=10.11$; $p<.01)$, thereby confirming $\mathrm{H} 3$.

We now turn to teaching health. A higher research quantity has no significant effect on teaching health $(\beta=-.03 ; p=.67)$, so we are not able to confirm neither H4a nor H4b. We also find that while higher $q$-quality (i.e., practical importance) of faculty research is associated with higher teaching health of a business school $(\beta=.22 ; p<.01)$, higher $r$-quality (i.e., rigor) is not $(\beta=.02$; 
$p=.69)$. A Wald test rejected the null hypothesis that the parameters are equal in size ( $\mathrm{F}=4.53 ; p$ $<.05)$, thereby confirming H5.

We find that research quantity may negatively affect external support $(\beta=-.17 ; p<.10)$, possibly showcasing competing demands on faculty time. The time faculty devotes to research quantity cannot be devoted to spending time with alumni and donors. In contrast, external support is higher with higher levels of $r$-quality $(\beta=.21 ; p<.01)$ and of $q$-quality $(\beta=.28 ; p<.01)$. A Wald test failed to reject the null hypothesis that the coefficients for $r$-quality and $q$-quality are equal in size $(\mathrm{F}=.28, p=.60)$. Taken together, these results confirm H6.

We find a positive effect of $r$-quality $(\beta=.17 ; p<.05)$ on institutional integrity, which confirms H7. We find no significant effect of research quantity on institutional integrity ( $\beta=.06$; $p=.45$ ), which we did not hypothesize. Interestingly, even though we also did not hypothesize, we find a positive and significant effect of $q$-quality on institutional integrity $(\beta=.25 ; p<.01)$.

We now turn to the managerial dimensions of business school health. We observe that schools with research with high $r$-quality tend to also have high leadership support $(\beta=.36 ; p<.01)$, high administrative support $(\beta=.26 ; p<.01)$, and high resource support $(\beta=.22 ; p<.01)$. We also find a positive association between $q$-quality and leadership support $(\beta=.14 ; p<.05)$, between $q$ quality and administrative support $(\beta=.18 ; p<.01)$, and between $q$-quality and resource support ( $\beta$ $=.10 ; p=.12$ ). We do not find positive associations between research quantity and any of the three managerial dimensions of business school health, i.e., leadership support $(\beta=.12 ; p=.18)$, administrative support $(\beta=-.04 ; p=.64)$, and resource support $(\beta=.01 ; p=.91)$.

\section{Study 2: In-Depth Interviews with (Associate) Deans and External Stakeholders}

Study 2 augments the faculty survey data with interviews with (associate) deans (i.e., representatives of principals) and with external stakeholders (i.e., leaders of external institutions 
of marketing scholarship, and senior marketing practitioners). Interviews took 35 minutes on average and yielded 164 pages of single-spaced transcripts.

Interviews with (associate) deans

We conducted phone interviews with 7 deans (4 former and 3 current) and 7 associate deans ( 2 former and 5 current) at 13 business schools in the U.S. and Europe (for full information on the protocol, see the Web Appendix, section W3), who are good informants (see guidelines by Merton and Kendall 1946). We opted for a "phenomenological" approach that is in-depth but nondirective in nature (Fournier 1998; Thompson, Locander and Pollio 1989). We audio-taped the interviews (except for two who did not give permission) which were subsequently transcribed by a research assistant and double-checked by one of the authors for accuracy. We then organized interview transcripts around recurring themes for analysis. These triangulation efforts resulted in three insights addressing the following three areas: (1) perceived misalignment in business schools' monitoring and compensation instruments, (2) the effects of the research task of faculty on research health, and (3) the effects of the research task of faculty on other dimensions of business school health.

First, regarding monitoring instruments, in line with our sociological agency framework and corroborating the views of research faculty in our survey, virtually all (associate) deans we interviewed expressed that there is an overreliance on effortless metrics (especially counting number of publications, but also number of citations) often at the expense of more effortful metrics such as creativity, literacy and relevance to non-academics. Of the 14 (associate) deans we interviewed, 11 recognized this overreliance on effortless metrics, and 9 explicitly mentioned they saw this trend as problematic for business schools, as highlighted by the following quotes:

"I definitely have seen just what I feel is an overreliance on the cohort table and the numbers. And I feel that that was something that I have kind of raised and I hadn't felt that I necessarily 
had any impact in terms of trying to say this is just one piece of information" [former vicedean for faculty at a U.S. FT top 25 school].

"When I started in 2000-2001, it was about the quality of the journals and what the outside reviewers said. So initially, there was very light weight put on citation counts and then over time, it started to increase a bit and then we got a couple of people elected to the promotion and tenure committee who were like 'we don't even have to look at quality, we can tell from the citation counts whether these things are any good or not" [former dean at a U.S. FT top 30 school].

"(Awards) should weigh a lot even when compared with contemporary productivity metrics, but in all honesty, contemporary productivity metrics are some of the most overused metrics to gauge academics" [current dean of research at a non-U.S. FT top 75 school].

"My frustration is when I'm drawing on a department chair for information, I get counts such as they had 27 publications, four in premier outlets, and this was the citation count" [current dean at a large public school in the U.S.].

"I remember when Google Scholar first came out there was a lot of skepticism about it... but that has definitely been adopted as the norm. And I think the ease of checking it and following it has caused a drift toward weighing it more highly" [former dean at a U.S. FT top 15 school].

"Are we just giving up on our ability to be doing all the heavy work? I think we are relying too much on the ease of numbers. [current dean at a U.S. FT top 75 school].

"I personally view it [a growing reliance on counting] as a very negative trend because people start gaming the citation count [current dean at a U.S. FT top 100 school].

"Now that we have metrics and now that people are scored on those metrics, I think that the system does - it shouldn't, but it does - put a greater emphasis on those numbers and less on, for example, creativity" [current vice-dean at a U.S. FT top 10 school].

"I think letters are becoming less diagnostic, but not because of their positivity, I think, but I think letter writers also feel less of an obligation to read the work" [current vice-dean at a U.S. FT top 10 school].

Regarding compensation instruments, we also observed considerable agreement in (associate)

deans' views. Nine out of the 14 (associate) deans we interviewed found business school professors overpaid for the research they do, in contrast with the views of research faculty in our survey. The following three quotes illustrate their views:

“...people come with their hands out all the time. I do not get it. It is just wrong. And I think we get paid really well. We have been historically. And we get things that other university faculty just do not get like guaranteed summers. I mean, talk to someone in public health, right? It has become an absurdity to me, and it's very unsustainable" [current dean at an FT top 75 school]. 
"The financial incentives that exist right now in the field are, to a certain extent, disturbing the market. I think the financing model of the top 100 business schools in the US sooner or later will explode... it is a crisis waiting to happen" [current dean of research at a non-U.S. FT top 75 school].

"Nowadays, it is too hard to get faculty to do things, so you start compensating, paying for everything." [current dean at a large public school in the U.S.].

Nearly all the (associate) deans we interviewed expressed a negative opinion of publication bonuses, again in contrast with research faculty in our survey. The following two quotes are representative of this generalized negative feeling:

"We do not have bonuses for publications, and I do not find those a good idea, they may trigger perverse behaviors" [current vice-dean at a public non-U.S. business school].

"I think that at least among our faculty if a bonus were paid directly for a paper, it would make faculty feel like coin operated. And I think that would lead to a culture impact that would not serve us" [former dean at a U.S. FT top 15 school].

Second, regarding the effects of the research task of faculty on research health, the interviews largely confirmed that research quantity and research quality (both in $r$-quality and $q$-quality) are important for a business school's research health. Nine of our interviewees expressed a more positive view on the extent to which their school's faculty was achieving this on $r$-quality than on q-quality:

"Basic science tries to understand how the world works, applied science tries to develop applications. I believe that management research is now 99\% 'basic' and only 1\% 'applied'." [current vice-dean at a public non-U.S. business school]

"We like to see people who hit a homerun, like this is really good paper. (...) There's a lot of acceptance of low productivity rates if the quality of the home runs is there" [former deputy dean at a U.S. FT top 30 school].

"Huge transformation here. I think we are in the process of just becoming considerably more rigorous. And I think the junior faculty is looking stronger and stronger" [former dean at a U.S. urban private business school].

"I feel increasingly frustrated by the extent to which we talk to other academics and we do work that is not addressing the issues and questions that are really most pressing in the world of business or the world more broadly and that we could be a lot more relevant and we could be speaking to practice a lot more" [former vice-dean for faculty at a U.S. FT top 25 school]. 
"I would give that (a research center connecting faculty with local companies) as a beautiful example of zero return to a massive investment. We had a donor give 20 million dollars to set up this stupid research center and I cannot think of a damn thing that was useful that came out of that... It's sort of lipstick on a pig that pretends that we're really interacting with industry in a useful way" [current dean at a U.S. FT top 100 school].

"At some level most of the work that I see that goes on doesn't connect to management. (...) Sometimes the research is so technical that it's not acceptable to a broader audience" [former deputy dean at a U.S. FT top 30 school].

"When I look at what's in the journals it strikes me that most of it is pretty irrelevant to what's going on in the world. So, I think that's a huge issue." [Former dean at a U.S. FT top 30 school].

Third, regarding the effects of the research task of faculty on other dimensions of business school health, we observed significant variance in (associate) deans' views. While basically all the (associate) deans we interviewed viewed teaching health as fundamental to business school health, four of our interviewees expressed concerns with the impact of the research task of faculty on teaching health, as illustrated by the following two quotes:

"We have a management department...and I think at this point, there's maybe two people in there who could be teaching exec ed. And that is where your leadership people should be... and they just can't do it. At some level, we may kick ourselves out of business" [current dean at a U.S. FT top 75 school].

“...it seems every marketer wants to be a social scientist and wants to stop selling cookies. I mean, there are a lot of marketing scholars that fundamentally do not study marketing topics anymore and just look at topics that are generic social science research topics" [current dean of research at a non-U.S. FT top 75 school].

Similarly, several (associate) deans voiced concerns with the impact of the research task of faculty on other dimensions of business school health. The following quotes illustrate that these concerns often revolved around competing demands on faculty time:

"When I started back around 25 years ago, I think the demands on teaching, the demands for students, the demands to speaking to alumni, the demands on having an impact on practice, demands on research, demands on monitoring $\mathrm{PhD}$ students... I think we're almost like businesses now...". [current vice-dean at a U.S. FT top 10 school].

"If you keep on asking more and more of people, then inevitably you may push them towards more egoistic behaviors. My own normative statement is: 'ask for great stuff, but do not ask too much of it."' [current dean of research at a non-U.S. FT top 75 school]. 
"What we do is to work very hard on the staff side. The staff spend an awful lot of time setting up relationships with recruiters and with our alumni and companies." [current dean of research at a non-U.S. FT top 75 school].

Interviews with external stakeholders

We conducted phone interviews with eight external stakeholders including (1) current or past leaders at five external institutions of marketing scholarship (e.g., The Marketing Science Institute (MSI)); and (2) sophisticated marketing practitioners at three large multinational firms (the former Global CMO of a large multinational technology corporation, the current $\mathrm{CEO}$, and an EVP at two of the world's largest market research firms), who are or have been involved with these external institutions.

The interviews with external stakeholders yielded three key insights: (1) endorsement and cohesion institutions play a critical role in business schools' monitoring of research faculty, (2) cohesion institutions can play a key role in promoting socialization between academics and practitioners, and (3) external stakeholders are concerned with the practical importance (i.e., $q$ quality) of academic research produced in business schools.

First, consistent with our theorizing, interviewees expressed that business schools track endorsement institutions' monitoring of their faculty. As a former chair-elect of the AMA Board of Directors pointed out,

"(The) AMA aims to promote the creation of cutting-edge marketing content both through the journals and through the awards inside the Foundation. Faculty go back and list those awards on their annual reviews and use that as part of their argument for where they should stand inside their institution."

Interviewees also confirmed that cohesion institutions enable the provision of a common base of knowledge, sharing of such knowledge, or data access that supports research faculty in 
their research agenda ${ }^{16}$. Therefore, business schools monitor the role or reputation of their research faculty in such cohesion institutions:

"MSI's Young Scholars program helps juniors develop a strong cohort. They get more invited talks, it gets them the opportunities to be recruited, and it starts research collaborations." [former executive director of MSI].

Second, some of our interviewees pointed out that cohesion institutions can stimulate collaboration not only among academics but also between academics and practitioners. The following quotes illustrate this view:

"I think institutions such as MSI or the ISBM can facilitate research that has both academic rigor and has got practical merit." [former director of a cohesion institution that bridges academia and practice].

"At every conference, we have a panel of practitioners and a practitioner speaker. And people like that." [co-founder of a cohesion institution that bridges academia and practice].

"What I found interesting about the "7 Big Problems in Marketing" work at the AMA is that we were really trying to get at which problems practitioners today are facing, or that we see coming... and those were defined kind of collectively between academics and practitioners." [former Global CMO of a large multinational technology corporation].

"In my last trip [to an MSI meeting], in San Francisco right before COVID-19, there was a cocktail where we had various academics explaining their research, with whiteboards, we could walk out and talk about their research, etc... It was really interesting." [current EVP at one of the world's largest market research firms].

Third, nearly all external stakeholders expressed concerns with the academic research

produced in business schools, namely its lack of $q$-quality:

"[Academic research in business schools] feels like a small set of people speaking to each other about something that nobody cares about. I may be a little harsh here, but it is often not applicable to the kind of problems I see..." [current senior executive at a cohesion institution that bridges academia and practice].

"I think there is a stereotype we have on our side is that academic research is 'out of touch' with reality." [current EVP at one of the world's largest market research firms].

"Academic research is highly differentiating but not necessarily as relevant... And obviously, the two things are easily at odds... If you are highly relevant, you are not "different". And I think that's the challenge. Does academic research want to be more relevant? Or does it want

\footnotetext{
${ }^{16}$ Note that cohesion institutions often go beyond supporting their members' research agendas and help with agenda setting (e.g., MSI research priorities).
} 
to maintain its differentiation? Because while it clearly is rigorous, it is largely unassailable, I would say, to the business community..." [current CEO at a leading market research firm in the US].

"Most of my peers in the business functions [marketing, strategy and corporate reputation] would only look at academic research if it was sort of quoted in the context of another business story. (...) Our analytics folks will definitely go deeper into academic papers specifically if it's helping them." [current CEO at a leading market research firm in the US].

\section{DISCUSSION: IMPLICATIONS AND LIMITATIONS}

We now discuss implications of our studies for business school faculty and business schools as principals. Then, we list the main limitations of the present paper and how future work could enrich our knowledge further.

\section{Implications}

One of our main findings is that badly designed incentive systems have a more negative influence on the ( $r$ - and $q$-) quality of research than on research quantity. Specifically, our respondents felt that metrics such as the number of publications which are easy to collect receive too much weight in faculty evaluation while effortful metrics such as creativity, literacy, and relevance to non-academic audiences, receive too little weight. We advocate finding a better balance (i.e., a redistribution of weights) between low-effort and effortful metrics. More specifically, business schools should:

- Improve otherwise low-effort metrics such as number of publications or citations to be more informative (i.e., making the effortless more effortful). For example, aggregate citation counts should be complemented by analyzing (1) whether highly-cited papers of a scholar were original contributions in premier journals or, rather, review articles in secondary journals; (2) whether a scholar's articles are consistently in the top $20 \%$ cited 
papers or consistently in the bottom $20 \%$ cited papers of a journal; and (3) whether the top 5 or 10 cited articles of a scholar were published in premier or secondary journals.

- Consider low-effort metrics such as the number of publications or citations only as a starting point for faculty evaluation rather than an end point. For instance, for citations, it would be meaningful to rank a professor's work according to Web of Science citations, after which the 5 highest ranked articles are assigned for reading to a committee, which assesses the $r$ - and $q$-quality of the respective 5 papers based on reading them.

- Dedicate more effort to reading and evaluating than counting when assessing faculty research. For instance, some schools establish reading committees and empower departments to take a more holistic approach to decision-making. Ideally, these committees provide thorough evaluations of the work, rather than a mere summary of the papers. To reduce burden on P\&T committee members, schools can ask the candidate to pick her or his 3-5 best papers and ensure that evaluators especially read and discuss those papers. One (associate) dean also told us about the practice of assigning discussants on specific papers of a candidate up for P\&T evaluation to stimulate reading and evaluation.

- Add creativity and literacy of scholarly work to the evaluation process as well as to the training and coaching of doctoral students and young faculty (Stewart 2020). History and philosophy of science, as well as history of marketing thought, should find their way back into our PhD curricula. Innovation management as a field has shown that creativity, ideation, idea development, are all processes that can be trained with tools (e.g., Burroughs, et al. 2011); doctoral students and young faculty could be trained on such tools.

- Make the system of reference letters used for P\&T decisions more effective, by (1) explicitly providing a cohort list to which the candidate should be compared, (2) making 
evaluation criteria such as creativity and literacy explicit, and (3) involving a more heterogenous set of letter writers. Schools should prevent gaming of cohort lists. For instance, schools can decide on a universal set of reference schools, such as the 10-20 schools that perform similarly or a little better on the FT overall or UT Dallas research rankings. The cohort for a specific candidate in a P\&T process could consist of two types of faculty members of the reference schools: (1) all research faculty with a similar "time since doctoral degree" (e.g., +/- 1-2 years); (2) all faculty of the rank the candidate is considered for that graduated (doctoral degree), at most, 5 years prior to the candidate. Academic letter writers should also not be confined to specialty but be sourced from the entire discipline across silos. And why not also allow non-academics to write letters? One school we studied included alumni, students, and professionals, with a typical P\&T package having up to 50 letters.

On compensation, we found that faculty members feel undercompensated while several (associate) deans feel the faculty is constantly haggling for raises, without sufficiently internalizing the school's long-term health. This misalignment is less present at better performing schools than at worse performing schools. We are optimistic that this poor alignment may fade in the future. First, although the COVID-19 crisis and its dramatic impact on higher education will very likely lead to a major downward adjustment of compensation of research faculty (Perry 2020; CNN), pressure on faculty to contribute to their business school's long-term health will simultaneously increase, ultimately leading to a better principal-agent alignment. This is because business school principals are likely to highly appreciate the efforts of their faculty while faculty will (hopefully) understand their sacrifice is necessary to mitigate an unusual crisis threatening the survival of their 
institutions. In other words, "we're all in this together" will have real meaning in the alignment of compensation expectations.

Second, we believe that business schools will gradually get better at increasing the leverage they have over faculty by aligning them more with the mission of the school rather than their own self-interest. Posner (2010) would call this fostering a "high-commitment environment," in which agents emotionally identify with the principal and value "nonpecuniary rewards of work motivated by a sense of commitment" (p. 10). Here are some suggestions for how to do this:

- Schools should give faculty a better understanding of the entire organization, its operations, and its finances. Some schools have a well-developed habit of organizing faculty meetings where they transparently cover all aspects of the school's business. In one of the business schools we serve, faculty meetings periodically cover the school's income statement, sales forecasts, and balance sheet to increase faculty's understanding of the economics of the school. Others do not or purposefully hide financials, which prohibits the faculty from seeing their salary and contribution in the context of the bigger picture.

- Schools should showcase what administrators, (associate) deans and other senior faculty do on a day-to-day basis to improve the school's health. We have seen "a day in the life of..." presentations by deans to give faculty a better idea of what kinds of internal and external pressures s/he is facing. Transparency on such direct contributions to the health of the school may put the research accomplishments of a research faculty member (such as another $J M$ or $J M R$ publication being freshly accepted) into perspective.

- Schools could promote teamwork and collaboration among faculty within the same school. Such collaborations may stimulate faculty's emotional identification with the school and its mission. While considering such promotion of internal collaboration, schools also need 
to put checks in place against undesirable practices, such as: (1) forcing people into collaborations; (2) free-riding in collaborations; or (3) junior faculty trading in coauthorships for political or teaching support, often from senior faculty, among others.

Another way would be for schools to ensure their research faculty meet the outside world also from a compensation perspective. We feel that business school professors would gain from practicing in their professional area just like medical school professors see patients or law professors assist in writing and enforcing legislation, practicing law, or performing expert witness services. Why are business school professors different? Why are so few business school professors even partially active as business professionals? Outside activity by professors would also give those professors an outside valuation on their time. Very likely, such external valuation could: (1) bring the compensation demanded from the school more in line with actual valuation by external stakeholders; and (2) complement the pecuniary reward from the school lowering the faculty's dependency on the school's paycheck.

Another main set of findings relates to the effect of the research task of faculty on business school health. We find that research $r$ - and $q$-quality are stronger drivers of business school health than research quantity. Both faculty and (associate) deans consider $r$-quality of research to be more important as a driver of research health of a school than research quantity. The results on $q$-quality are more mixed. While the survey results indicate that $q$-quality is not congruent with research health, they show that it is congruent with teaching health, external support, and institutional integrity. At the same time, the (associate) deans consider $q$-quality to be fundamental to business school health. The (associate) deans report that the schools they lead have made more progress on $r$-quality than on $q$-quality and that they are concerned about a further decline in $q$-quality in recent years. 
We thus recommend that business schools steer their research audits to more effectively stimulate the $r$-quality and/or the $q$-quality of their faculty's research. For schools seeking to increase $r$-quality, the following questions could be used:

- Are we allocating money to the right people (e.g., is it focused enough on quality)?

- Is the "water cooler" chat about high-quality research?

- Are our research metrics sufficiently rewarding quality?

- Are we represented enough on the Editorial Review Boards of the best journals in the field? For schools seeking to increase q-quality, the following questions could be used:

- Is the school lenient enough or does it sufficiently stimulate consulting by faculty high in r-quality? (e.g., Roberts, Kayande and Stremersch 2014 found many dual-impact papers to originate in senior faculty consulting).

- Does our doctoral program do enough to socialize our students with practice, while maintaining a high $r$-quality focus?

- Are our research centers fundamentally engaging with practice or are they mostly "lipstick on a pig" (as one our interviewed associate deans put it)?

- Are our research faculty high in $r$-quality teaching in executive MBA or open and custom programs? Teaching in undergraduate, or even daytime MBA programs provides less socialization with practice than executive education.

- When hiring new faculty, do we try to balance the portfolio of research faculty profiles to ensure excellence both in $r$-quality and $q$-quality ${ }^{17}$

\footnotetext{
${ }^{17}$ One way to screen candidates on their potential to produce high $q$-quality research may be to include practitioners in the search committees for new faculty.
} 
- In faculty assessment committees, do committee members evaluate and appreciate high $q$ quality publications (e.g., in scholarly journals as well as top-tier journals or magazines that target practicing managers $\left.{ }^{18}\right)$ ?

Research audits are conducted in a number of ways such as internally with a multidepartment committee chaired by the research dean or, better still, externally with a panel of outside faculty with outstanding research records, preferably on both $r$ - and $q$-quality, and with a good understanding of business school health. For schools that have not done a research audit for a while, the above findings and suggestions should stimulate them to organize such audits, preferably on regular intervals. For schools that already perform such audits regularly, the topics noted above, based on our findings, should make such audits more impactful and focused on today's major challenges of business schools.

To best inform such audits, business schools can benchmark their experiences with those of successful business schools, or role models, which can serve as yardsticks for improving their research faculty incentive systems. Role models help clarify an "aspiration gap", i.e., the difference between a level of performance that one aspires to achieve, and the level of performance that one already has (Ray 2006). Moreover, role models are "inherently multidimensional" (Ray 2006). For instance, different business schools have different aspiration levels, and thus place different weights across different dimensions of the research task they want to optimize. Hence, each business school should benchmark its faculty research incentive system with those of a weighted combination of other business schools chosen to generate a "synthetic role model" that closely resembles the performance that the school aspires on research quantity, $r$-quality, and $q$-quality. As an illustration of the usage of these "synthetic role models," we present, in Table 5, three

\footnotetext{
${ }^{18}$ Examples include the Harvard Business Review (with a readership of 200,000+), MIT Sloan Management Review, California Management Review, and the recently launched Management and Business Review (MBR).
} 
stylized synthetic role models we generated based on our qualitative interviews. These illustrations may serve as inspiration for those schools seeking to increase their performance in research quantity (SRM-Qty), $r$-quality (SRM-R), or $q$-quality (SRM-Q).

Our paper also has a clear implication for faculty of business schools: they will need to work on increasing $q$-quality without decreasing $r$-quality of their work (we agree with Vermeulen (2005) that the two are not necessarily contradictory). Some specific suggestions for faculty to improve the present situation are:

- Faculty need to consciously strengthen the cohesion institutions that support the promotion of socialization with practitioners (e.g., AMA, MSI, TPM). Within such cohesion institutions, we could stimulate action that increases $q$-quality of research of high $r$-quality. Should MSI give fewer, but larger grants? Should MSI assign a corporate sponsor directly to steering such larger grants? Or only grant funding to research teams combining academics and practitioners? Under its present organizational structure (the executive team being fully composed solely of practitioners), the AMA has failed to make the connection between academics and practitioners (as noted by the representative from the AMA we interviewed). Can faculty aid in building a new model within the AMA?

- As faculty, we need to embrace consulting and executive education assignments as learning ground for our research and not as an activity separate from our research. The translation of such experiences to scholarly research may be effortful, but such experiences are critical to identifying big, dual-impact, research topics.

\section{Limitations}

There are some limitations of this research that may give rise to future work. First, our empirical evidence is all self-reported from a survey and interviews. While self-reports enable us 
to cover a broad set of topics, each of the relationships we establish could potentially fuel secondary data research. There have been some secondary data studies that examine the effect of research on teaching, but much less so involving other business school health dimensions, such as external support or institutional integrity, all of which could be gauged by secondary data also (e.g., endowment statistics and online chatter of student communities).

Second, our empirical evidence and conceptual derivation only limitedly exposes the causal mechanisms at work. In fact, we have been prudent throughout the paper to not claim causation, rather merely claim correlation. Thus, future research that goes from correlation to causation would be very fruitful; it could also document more precisely the nature of the feedback mechanisms that we introduced. Future research could also more elaborately document the behavioral mechanisms in place that makes business schools excessively monitor numbers and insufficiently monitor creativity or literacy. One can conceive behavioral experiments with academic assessors on research metrics, how people use them, and under which conditions decisions can be (de)biased.

Third, we explored the variance in incentive misalignment across schools on a limited number of school descriptors. Research could easily expand on a larger set of school descriptors. For instance, do the effects we study depend on whether the school offers more or less executive education, where the school is located (US vs international), whether the school is strongly integrated into a larger university system or not, whether the school is private or public, or how high the tuition fees are that it is charging?

Fourth, we took a step beyond our empirical inquiry to conceptualize what business schools could do to positively affect the present state-of-affairs. Some of the recommendations we gave seem easy to implement, others are more difficult and would benefit from a more elaborate 
conceptualization than the length and scope of this paper allow. For instance, how can business schools create a stronger sense of common purpose among its faculty such that the faculty is less self-interest seeking? Or, how can business schools favor more reading and less counting, and how can they better monitor creativity and literacy? The latter question can also fuel scientometric research to address some of the alternative metrics we suggest.

Despite these limitations, we feel that we have made a significant contribution to understanding the role of faculty research in business school health. At the very least, we hope that we have sparked a dialogue to get more (marketing) faculty and business school administrators to re-think how to make business schools healthier. 


\section{Figure 1:}

\section{A Sociological Principal-Agent Perspective on Academic Research in Business Schools}

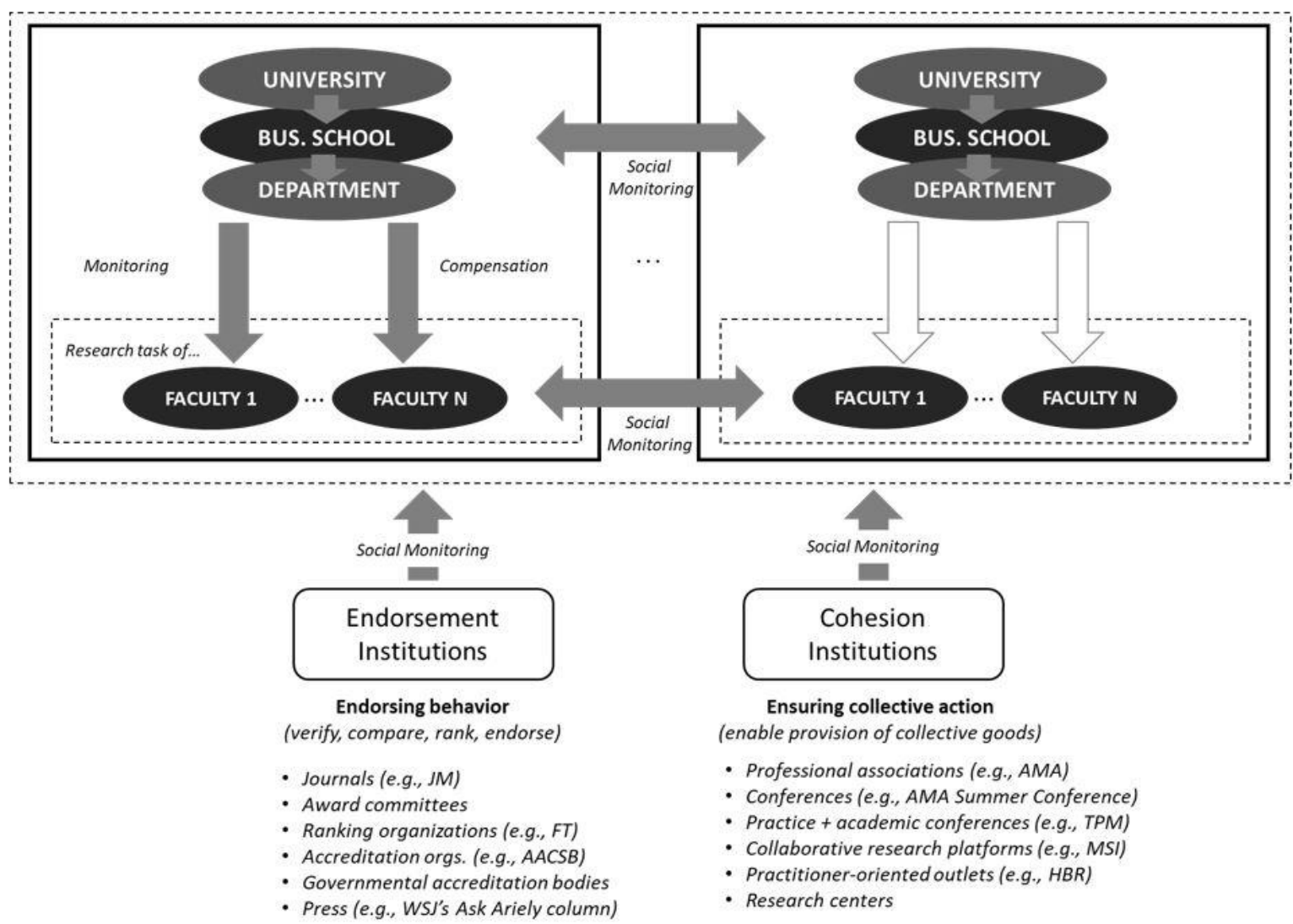


Figure 2:

The Effect of the Faculty Research Incentive System on the Research Task of Faculty and Business School Health

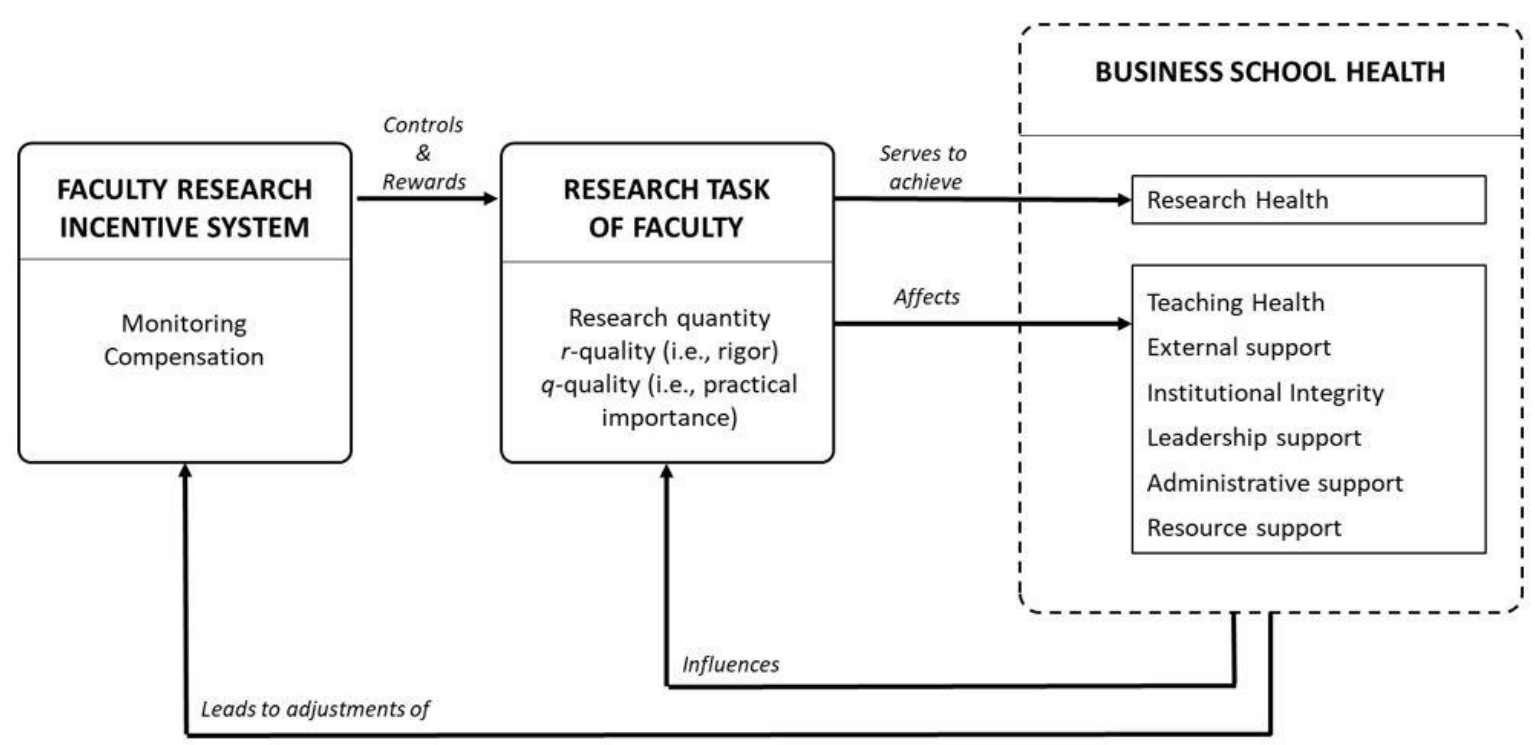




\section{Figure 3:}

\section{Misalignment of Incentive Instruments}

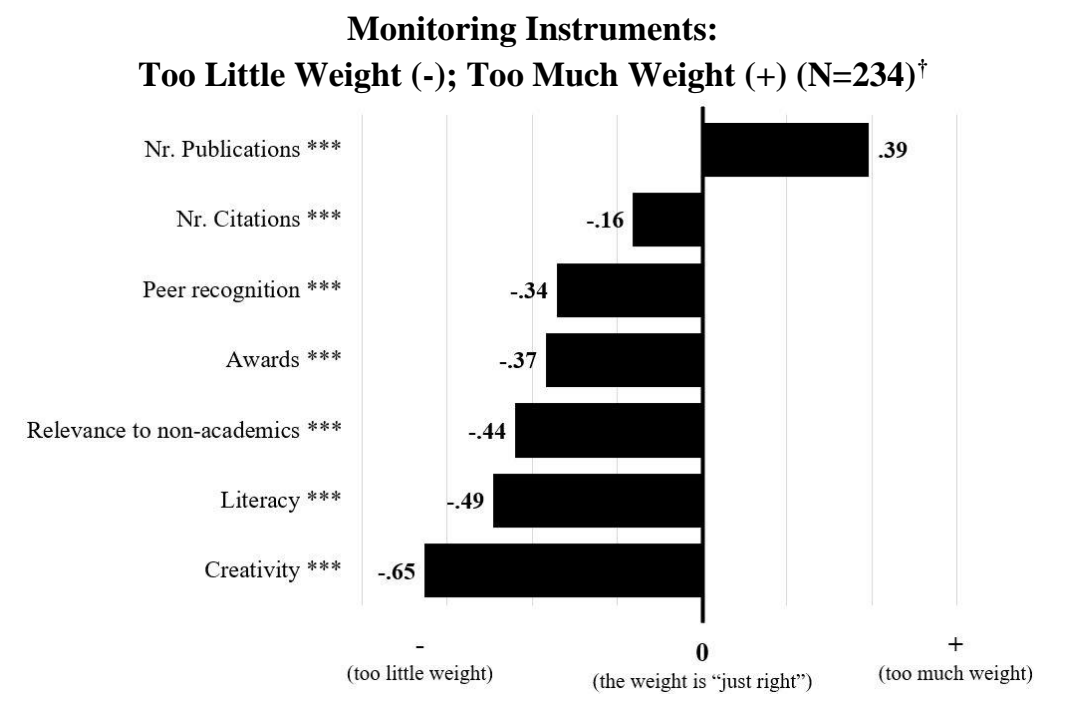

$\dagger$ The question asked, for each monitoring instrument, was "At your school, do you feel that the following metrics on research faculty receive too much or too little weight?" and the response scale was: $-2=$ Far too little weight, $-1=$ Too little weight, $0=$ The weight is just right, $+1=$ Too much weight,$+2=$ Far too much weight.

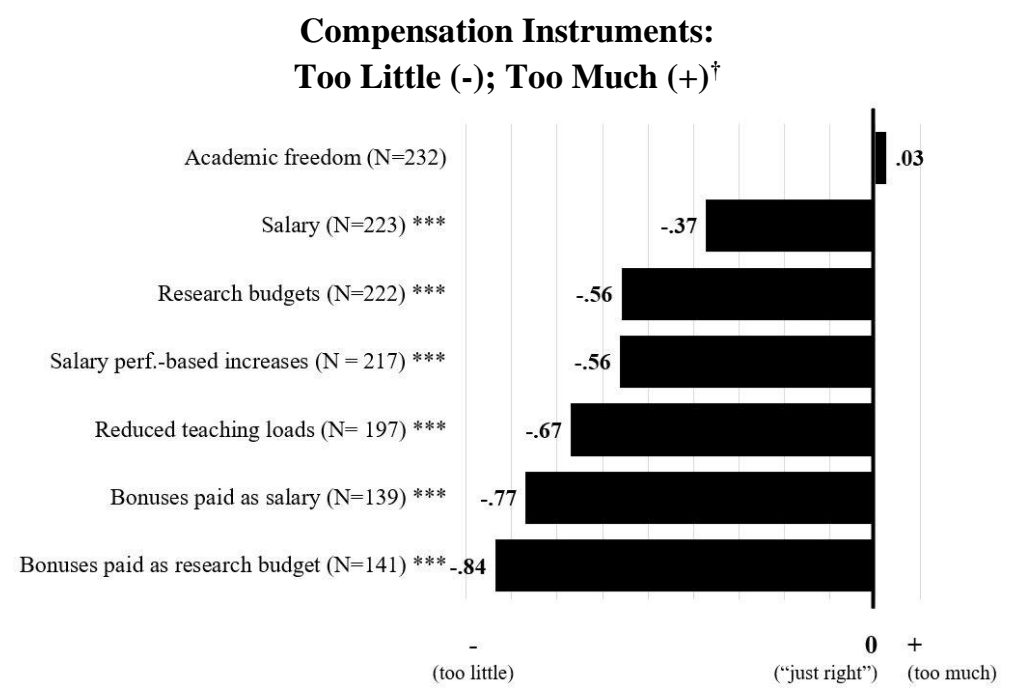

$\uparrow$ The question asked, for each compensation instrument, was "At your school, do you feel that research faculty receive too little or too much of each of the following as rewards for their research?" and the response scale was: -2 $=$ Far too little, $-1=$ Too little, $0=$ Just right,$+1=$ Too much,$+2=$ Far too much.

The asterisks represent the $p$-values for t-tests comparing the mean score for the perceived appropriateness of the weight given to each instrument to 0 (which means (the weight is) "just right"): ${ }^{*} p<.10 ; * *<<.05 ; * * * p<.01$. All p-values are two-sided. In the case of compensation questions, respondents could answer "not applicable", hence we indicate the sample used to compute mean responses next to each compensation instrument's label in the right panel. 


\section{Figure 4:}

\section{Misalignment of Incentive Instruments:}

\section{Variation According to Research Quantity and $r$-quality (Left Panel) and $q$-quality (Right Panel) ${ }^{\dagger}$}

Misalignment of Faculty Research Incentive Systems for Schools with Low vs. High Research Quantity and Low vs. High r-quality"

\begin{tabular}{|c|c|c|}
\hline High & $\begin{array}{c}\mathrm{MAD}^{\mathrm{M}}=.51 \\
\mathrm{MAD}^{\mathrm{C}}=.55 \\
\mathrm{~N}=44\end{array}$ & $\begin{array}{c}\mathrm{MAD}^{\mathrm{M}}=.43 \\
\mathrm{MAD}^{\mathrm{C}}=.53 \\
\mathrm{~N}=75\end{array}$ \\
\hline \multirow[t]{2}{*}{ Low } & $\begin{array}{c}\mathrm{MAD}^{\mathrm{M}}=.70 \\
\mathrm{MAD}^{\mathrm{C}}=.74 \\
\mathrm{~N}=76\end{array}$ & $\begin{array}{c}\mathrm{MAD}^{\mathrm{M}}=.68 \\
\mathrm{MAD}^{\mathrm{C}}=.70 \\
\mathrm{~N}=39\end{array}$ \\
\hline & Low & High \\
\hline
\end{tabular}

Misalignment of Faculty Research Incentive Systems for Schools with Low vs. High Research Quantity and Low vs. High q-quality*

\begin{tabular}{|c|c|c|}
\hline High & $\begin{array}{c}\mathrm{MAD}^{\mathrm{M}}=.53 \\
\mathrm{MAD}^{\mathrm{C}}=.60 \\
\mathrm{~N}=51\end{array}$ & $\begin{array}{c}\mathrm{MAD}^{\mathrm{M}}=.46 \\
\mathrm{MAD}^{\mathrm{C}}=.59 \\
\mathrm{~N}=67\end{array}$ \\
\hline \multirow[t]{2}{*}{ Low } & $\begin{array}{c}\mathrm{MAD}^{\mathrm{M}}=.71 \\
\mathrm{MAD}^{\mathrm{C}}=.72 \\
\mathrm{~N}=69\end{array}$ & $\begin{array}{c}\mathrm{MAD}^{\mathrm{M}}=.59 \\
\mathrm{MAD}^{\mathrm{C}}=.58 \\
\mathrm{~N}=47\end{array}$ \\
\hline & Low & High \\
\hline
\end{tabular}

$\dagger$ To measure whether faculty research incentive instruments are improperly weighted (i.e., misaligned) we computed mean absolute deviations (MAD). Specifically, we first compute individual mean absolute deviation scores, which are the averages of the absolute deviations between a respondent's scores in all items of a given scale (say, all seven monitoring instruments) and the central point of the scale (which indicates that the weight given to a given instrument is "just right"). The values reported in this figure are the averages, across respondents in a given cell, of these individual MAD scores for monitoring instruments $\left(\mathrm{MAD}^{\mathrm{M}}\right)$, and for compensation instruments $\left(\mathrm{MAD}^{\mathrm{C}}\right)$.

To avoid a skewed split, we randomly classified respondents in the "median category" (e.g., those with a score of "4" for research quantity) as either "below median" or "above median" using a proportion that ensures that approximately half of the respondents are classified as "below median" and the other half as "above median" in each dimension. 
Table 1 - Selected Papers on the Role of Academic Research in Business Schools (1/2)

\begin{tabular}{|c|c|c|c|c|c|}
\hline Paper ${ }^{*}$ & Field & $\begin{array}{l}\text { \# Cites } \\
\text { (Google) }\end{array}$ & Focus $^{\dagger}$ & $\begin{array}{l}\text { Conceptual or } \\
\text { Empirical }\end{array}$ & Short Summary \\
\hline $\begin{array}{l}\text { Bettis } \\
(S M J \text { 2012) }\end{array}$ & Strategy & 124 & Rigor of Research & $\mathrm{C}$ & $\begin{array}{l}\text { Data snooping may be prevalent among strategy researchers, even though } \\
\text { evidence is lacking. This raises serious issues for the future of strategic } \\
\text { management research. }\end{array}$ \\
\hline $\begin{array}{l}\text { Jaworski } \\
(J M \text { 2011) }\end{array}$ & Marketing & 168 & $\begin{array}{l}\text { Practical Importance } \\
\text { of Research }\end{array}$ & $\mathrm{C}$ & $\begin{array}{l}\text { The author defines managerial relevance. Research faculty in marketing } \\
\text { need a better understanding of managerial practice to conduct research that } \\
\text { is relevant to marketing managers' needs. To do so, marketing scholars } \\
\text { must spend more time with managers. }\end{array}$ \\
\hline $\begin{array}{l}\text { Kaplan } \\
\text { (Acc. Review 2011) }\end{array}$ & Accounting & 257 & $\begin{array}{l}\text { Practical Importance } \\
\text { of Research }\end{array}$ & $\mathrm{C}$ & $\begin{array}{l}\text { Accounting scholars have distanced themselves from the professional } \\
\text { practice of accounting. Accounting scholars should devote more resources } \\
\text { to fundamentally understand contemporary and future practice. }\end{array}$ \\
\hline $\begin{array}{l}\text { Lehmann, McAlister } \\
\text { and Staelin } \\
(J M \text { 2011) }\end{array}$ & Marketing & 135 & $\begin{array}{l}\text { Practical Importance } \\
\text { of Research }\end{array}$ & $\mathrm{E}$ & $\begin{array}{l}\text { The level of analytical rigor has risen steadily in academic marketing } \\
\text { journals. While, ceteris paribus, rigor is desirable, other desirable } \\
\text { characteristics, such as practical importance, communicability, and } \\
\text { simplicity, have been downplayed, to the detriment of the field of } \\
\text { marketing. }\end{array}$ \\
\hline $\begin{array}{l}\text { Lilien } \\
(J M 2011)\end{array}$ & Marketing & 141 & $\begin{array}{l}\text { Adoption of Research } \\
\text { by Practice }\end{array}$ & $\mathrm{C}$ & $\begin{array}{l}\text { There is a large and widening academic-practitioner gap in the research } \\
\text { published by marketing scholars. There are many successful marketing } \\
\text { model developments, but their level of usage in practice is low. }\end{array}$ \\
\hline $\begin{array}{l}\text { Reibstein, Day and } \\
\text { Wind (JM 2009) }\end{array}$ & Marketing & 376 & $\begin{array}{l}\text { Practical Importance } \\
\text { of Research }\end{array}$ & $\mathrm{C}$ & $\begin{array}{l}\text { The widening divergence between marketing academia and practice has } \\
\text { become detrimental to the long-term health of the field. }\end{array}$ \\
\hline $\begin{array}{l}\text { Mitra and Golder } \\
(J M \text { 2008) }\end{array}$ & Marketing & 50 & $\begin{array}{l}\text { Consequences of } \\
\text { Research for B- } \\
\text { Schools }\end{array}$ & $\mathrm{E}$ & $\begin{array}{l}\text { Academic research has positive long-term effects on the perceptions of } \\
\text { academics, recruiters, and program applicants, and on education } \\
\text { performance. A persistent increase of three single-author A-level articles } \\
\text { per year is associated with an improved MBA ranking by one place. }\end{array}$ \\
\hline $\begin{array}{l}\text { Rosemann and Vessey } \\
(M I S Q 2008)\end{array}$ & $\begin{array}{l}\text { Information } \\
\text { Systems }\end{array}$ & 402 & $\begin{array}{l}\text { Practical Importance } \\
\text { of Research }\end{array}$ & $\mathrm{C}$ & $\begin{array}{l}\text { To improve practical importance, IS researchers should combine rigor and } \\
\text { relevance by conducting applicability checks with practitioners. }\end{array}$ \\
\hline $\begin{array}{l}\text { Bartunek } \\
(A M J 2007)\end{array}$ & Management & 483 & $\begin{array}{l}\text { Practical Importance } \\
\text { of Research \& } \\
\text { Adoption of Research } \\
\text { by Practice }\end{array}$ & $\mathrm{C}$ & $\begin{array}{l}\text { Management researchers need to develop a "relational scholarship of } \\
\text { integration" with practitioners, i.e., develop fuller and emotionally engaging } \\
\text { relationships in which each has an equal role, rather than being restricted to } \\
\text { distant and one-sided "translation" efforts. }\end{array}$ \\
\hline
\end{tabular}

${ }^{*}$ We constrained the selection of articles in Table 1 to those published in journals on the UTD list.

** We collected the number of Google Scholar citations for the listed papers between April 8 and April 16, 2020.

$\dagger$ While many papers cover multiple dimensions, we attempted to define the focus of the respective papers rather narrowly. The four dimensions we categorize papers on are: (1) consequences of research for B-schools, which includes papers that explicitly take a business school perspective (as contrasted to a fieldperspective); (2) practical importance of research, which includes papers that address threats to $q$-quality such as the gap between academia and practice, from the perspective of academics; (3) adoption of research by practice, which includes papers that address the limited application of academic research, from the perspective of practitioners; (4) rigor of research, which includes papers that address threats to $r$-quality such as low replicability of studies, low rigor and scientific integrity of research. 
Table 1 - Selected Papers on the Role of Academic Research in Business Schools (2/2)

\begin{tabular}{|c|c|c|c|c|c|}
\hline Paper* & Field & $\begin{array}{l}\text { \# Cites** } \\
\text { (Google) } \\
\end{array}$ & Focus $^{\dagger}$ & $\begin{array}{c}\text { Conceptual or } \\
\text { Empirical } \\
\end{array}$ & Short Summary \\
\hline $\begin{array}{l}\text { Gulati } \\
(A M J \text { 2007) }\end{array}$ & Management & 460 & $\begin{array}{l}\text { Practical Importance of } \\
\text { Research \& Rigor of } \\
\text { Research }\end{array}$ & $\mathrm{C}$ & $\begin{array}{l}\text { Many "serious scholars" presume that colleagues writing for practitioners } \\
\text { ("management types") lack rigor, and those writing primarily for other } \\
\text { scholars lack practical importance. It is important for management scholars to } \\
\text { seek out room for reconciliation between rigor and practical importance. }\end{array}$ \\
\hline $\begin{array}{l}\text { Rynes, Giluk and } \\
\text { Brown }(A M J \text { 2007) }\end{array}$ & Management & 569 & $\begin{array}{l}\text { Adoption of Research } \\
\text { by Practice }\end{array}$ & $\mathrm{E}$ & $\begin{array}{l}\text { Practitioner and bridge journals provide little coverage of some of the } \\
\text { research findings deemed most important by scholars. When they do offer } \\
\text { coverage, this coverage is often inconsistent with research evidence. }\end{array}$ \\
\hline $\begin{array}{l}\text { Shapiro, Kirkman and } \\
\text { Courtney (AMJ 2007) }\end{array}$ & Management & 416 & $\begin{array}{l}\text { Practical Importance of } \\
\text { Research }\end{array}$ & $\mathrm{E}$ & $\begin{array}{l}\text { The theory-practice gap stems not only from a "translation" problem (i.e., } \\
\text { translating research for a practice audience), but also from a "production" } \\
\text { problem (i.e., producing research that is relevant for a practice audience). }\end{array}$ \\
\hline $\begin{array}{l}\text { Tushman and O'Reilly } \\
\text { III (AMJ 2007) }\end{array}$ & Management & 253 & $\begin{array}{l}\text { Practical Importance of } \\
\text { Research }\end{array}$ & $\mathrm{C}$ & $\begin{array}{l}\text { Executive education is a fertile and underleveraged setting to shape research } \\
\text { that is both rigorous and relevant. }\end{array}$ \\
\hline $\begin{array}{l}\text { Bennis and O'Toole } \\
\left(H B R 2005^{\S}\right)\end{array}$ & Management & 2802 & $\begin{array}{l}\text { Practical Importance of } \\
\text { Research \& } \\
\text { Consequences of } \\
\text { Research for B-Schools }\end{array}$ & $\mathrm{C}$ & $\begin{array}{l}\text { Rigor crowded out most of the practical importance of the research conducted } \\
\text { at business schools. The science model may not be applicable to business } \\
\text { schools. Business is "essentially a human activity in which judgements are } \\
\text { made with messy, incomplete and incoherent data". }\end{array}$ \\
\hline $\begin{array}{l}\text { Vermeulen } \\
(A M J 2005)\end{array}$ & Management & 243 & $\begin{array}{l}\text { Practical Importance of } \\
\text { Research }\end{array}$ & $\mathrm{C}$ & $\begin{array}{l}\text { Research that lacks rigor cannot be relevant. Business school scholars should } \\
\text { strive to conduct research that "makes a difference". }\end{array}$ \\
\hline $\begin{array}{l}\text { Pfeffer and Fong } \\
\left(A M L E 2002^{\S}\right)\end{array}$ & Management & 2291 & $\begin{array}{l}\text { Practical Importance of } \\
\text { Research \& } \\
\text { Consequences of } \\
\text { Research for B-Schools }\end{array}$ & $\mathrm{E}$ & $\begin{array}{l}\text { Business school research is making a modest contribution to management } \\
\text { practice at best, especially when compared to research and ideas from } \\
\text { consulting firms, journalists, and companies. }\end{array}$ \\
\hline $\begin{array}{l}\text { Rynes, Bartunek and } \\
\text { Daft }(A M J 2001)\end{array}$ & Management & 1313 & $\begin{array}{l}\text { Practical Importance of } \\
\text { Research }\end{array}$ & $\mathrm{C}$ & $\begin{array}{l}\text { The diffusion of academic knowledge to practitioners is slow. Practical } \\
\text { knowledge gathered from practitioners can enhance scientific progress. }\end{array}$ \\
\hline $\begin{array}{l}\text { Trieschmann et al. } \\
(A M J \text { 2000) }\end{array}$ & Management & 363 & $\begin{array}{c}\text { Consequences of } \\
\text { Research for B-Schools }\end{array}$ & $\mathrm{E}$ & $\begin{array}{l}\text { Research performance (e.g., number of first-tier publications) and MBA } \\
\text { performance (e.g., business press rankings) have different determinants. }\end{array}$ \\
\hline $\begin{array}{l}\text { Benbasat and Zmud } \\
(M I S Q 1999)\end{array}$ & $\begin{array}{l}\text { Information } \\
\text { Systems }\end{array}$ & 1454 & $\begin{array}{l}\text { Practical Importance of } \\
\text { Research }\end{array}$ & $\mathrm{C}$ & $\begin{array}{l}\text { IS academic research lacks practical importance because it emulated the rigor } \\
\text { of other academic fields. }\end{array}$ \\
\hline $\begin{array}{l}\text { AMA Taskforce } \\
(J M 1988)\end{array}$ & Marketing & 65 & $\begin{array}{l}\text { Practical Importance of } \\
\text { Research }\end{array}$ & $\mathrm{C}$ & $\begin{array}{l}\text { Marketing suffers from several structural impediments to the development } \\
\text { and dissemination of knowledge with long-term impact. }\end{array}$ \\
\hline \multicolumn{6}{|c|}{$\begin{array}{l}\text { While many papers cover multiple dimensions, we attempted to define the focus of the respective papers rather narrowly. The four dimensions we categorize } \\
\text { papers on are: (1) consequences of research for B-schools, which includes papers that explicitly take a business school perspective (as contrasted to a field- } \\
\text { perspective); (2) practical importance of research, which includes papers that address threats to } q \text {-quality such as the gap between academia and practice, from } \\
\text { the perspective of academics; (3) adoption of research by practice, which includes papers that address the limited application of academic research, from the } \\
\text { perspective of practitioners; (4) rigor of research, which includes papers that address threats to } r \text {-quality such as low replicability of studies, low rigor and } \\
\text { scientific integrity of research. }\end{array}$} \\
\hline
\end{tabular}


Table 2:

Key Construct Definitions and Representative Papers*

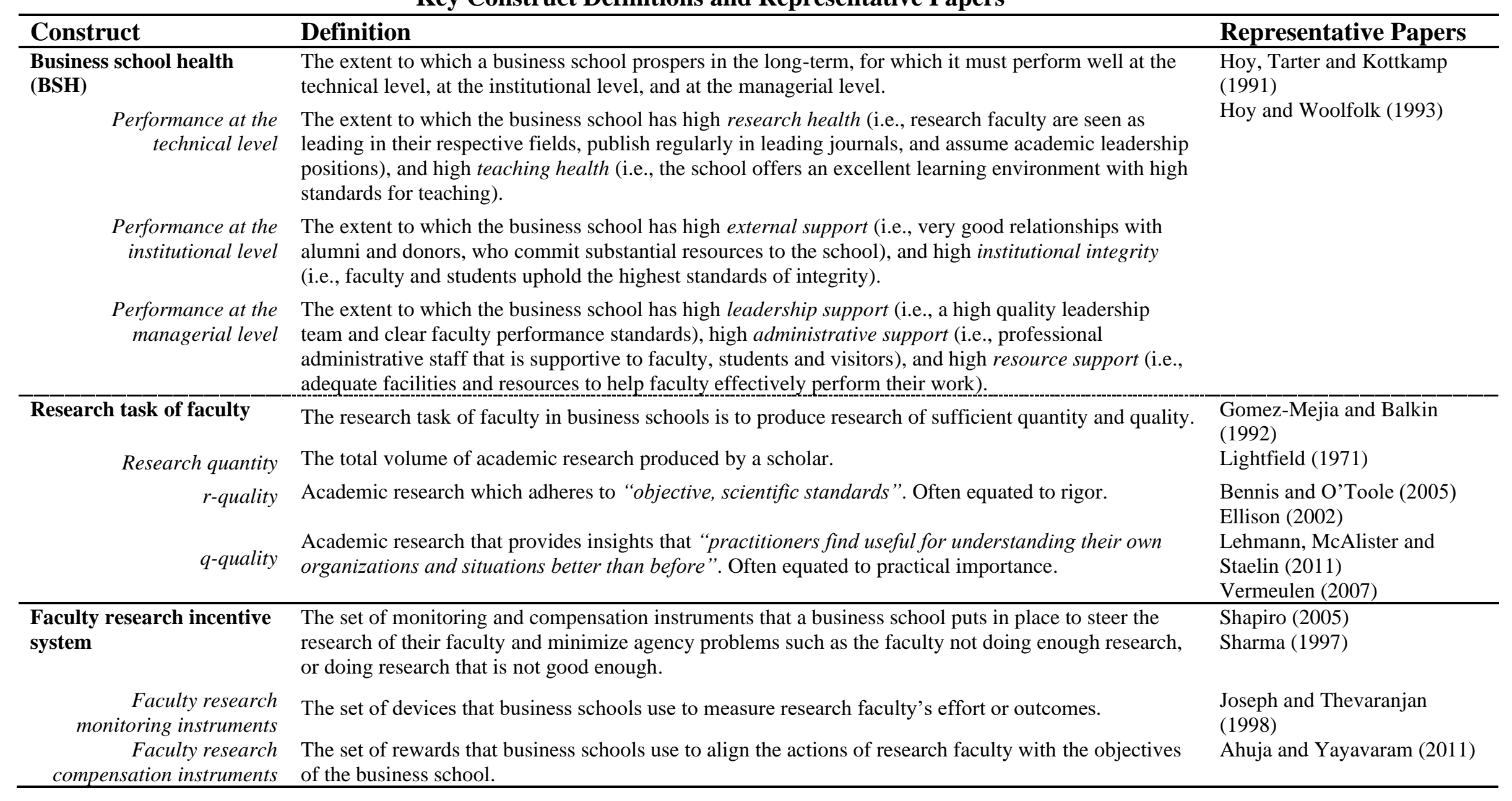

* For a complete set of construct definitions and corresponding operationalizations, see Table W1 in the Web Appendix, section W2. 
Table 3:

Business School Health Scale Items and Factor Loadings

\begin{tabular}{|c|c|c|}
\hline Items & $\begin{array}{l}\text { Factor } \\
\text { Loading } \\
\text { (PCA)* }\end{array}$ & $\begin{array}{c}\text { Factor } \\
\text { Loading } \\
(\text { CFA) } * *\end{array}$ \\
\hline \multicolumn{3}{|l|}{ 1. Research Health $(M=3.46 ; S D=.98 ; C R=.92 ; A V E=.78)^{\dagger}$} \\
\hline Our faculty is seen as leading in research by peers internationally. & .90 & .94 \\
\hline Our faculty publishes regularly in the best journals in their respective fields. & .89 & .91 \\
\hline Our faculty takes up leadership positions in the academic research community. & .86 & .80 \\
\hline \multicolumn{3}{|l|}{ 2. Teaching Health $(M=3.71 ; S D=.78 ; C R=.82 ; A V E=.60)^{\dagger}$} \\
\hline The school sets high standards for teaching. & .85 & .86 \\
\hline $\begin{array}{l}\text { Faculty accepts their responsibility towards providing students with an excellent } \\
\text { learning environment. }\end{array}$ & .80 & .86 \\
\hline Faculty that do well in the classroom are well respected in the school. & .84 & .71 \\
\hline \multicolumn{3}{|l|}{ 3. External Support $(M=3.35 ; S D=1.05 ; C R=.93 ; A V E=.81)^{\dagger}$} \\
\hline $\begin{array}{l}\text { Our school has the support of external stakeholders (alumni, donors) who are willing } \\
\text { and able to commit substantial resources (e.g., time, money) to the school. }\end{array}$ & .88 & .91 \\
\hline Our school has a very good relationship with external stakeholders (alumni, donors). & .87 & .92 \\
\hline $\begin{array}{l}\text { It is easy for our school to call on external stakeholders (alumni, donors) when times } \\
\text { get tough. }\end{array}$ & .85 & .88 \\
\hline \multicolumn{3}{|l|}{ 4. Institutional Integrity $(M=3.58 ; S D=.92 ; C R=.81 ; A V E=.59)^{\dagger}$} \\
\hline $\begin{array}{l}\text { Our school is able to maintain high integrity despite possible pressure from external } \\
\text { influencers. }\end{array}$ & .84 & .85 \\
\hline $\begin{array}{l}\text { Our school and faculty commit to the highest standards of integrity on a daily basis, } \\
\text { even if this comes at a short-term cost. }\end{array}$ & .80 & .89 \\
\hline $\begin{array}{l}\text { We communicate stronger ethical values to our student and faculty body than most of } \\
\text { our peers. }\end{array}$ & .75 & .75 \\
\hline \multicolumn{3}{|l|}{ 5. Leadership Support $(M=3.35 ; S D=1.06 ; C R=.89 ; A V E=.74)^{\dagger}$} \\
\hline The school's leadership maintains clear standards for faculty performance. & .86 & .90 \\
\hline The school's leadership lets faculty know what is expected of them. & .86 & .86 \\
\hline Our leadership team is of high quality. & .73 & .88 \\
\hline \multicolumn{3}{|l|}{ 6. Administrative Support $(M=3.51 ; S D=.91 ; C R=.84 ; A V E=.63)^{\dagger}$} \\
\hline $\begin{array}{l}\text { Our administrative staff (i.e., PA's and secretaries, program support staff, business } \\
\text { development staff, people division, etc.) is very supportive to faculty such that faculty } \\
\text { can focus on their primary responsibilities. }\end{array}$ & .77 & .85 \\
\hline $\begin{array}{l}\text { Our administrative staff is greatly appreciated by our students and by visitors to our } \\
\text { school. }\end{array}$ & .81 & .72 \\
\hline $\begin{array}{l}\text { Our administrative staff is very professional, and their competences are well } \\
\text { developed. }\end{array}$ & .79 & .90 \\
\hline \multicolumn{3}{|l|}{ 7. Resource Support $(M=3.65 ; S D=.92 ; C R=.80 ; A V E=.57)^{\dagger}$} \\
\hline Our school has great facilities in which to perform our work. & .74 & 69 \\
\hline We have adequate resources for all tasks assigned to us. & .86 & .89 \\
\hline $\begin{array}{l}\text { We have access to resources and materials when we need them to perform our work } \\
\text { effectively. }\end{array}$ & .85 & .95 \\
\hline
\end{tabular}

* Loadings from a principal component analysis with varimax rotation on the full set of 21 items without predetermined factors. Each item had its highest loading in its theorized factor, which we report here.

** Standardized loadings obtained from a confirmatory factor analysis with items preloaded on the seven business school health dimensions.

$\dagger \mathrm{M}=$ Mean; SD = Standard deviation; $\mathrm{CR}=$ Composite reliability (Bagozzi and Yi 1988); AVE = Average variance extracted (Fornell and Larcker 1981). 
Table 4:

Impact of Faculty Research on Business School Health ${ }^{\dagger}$

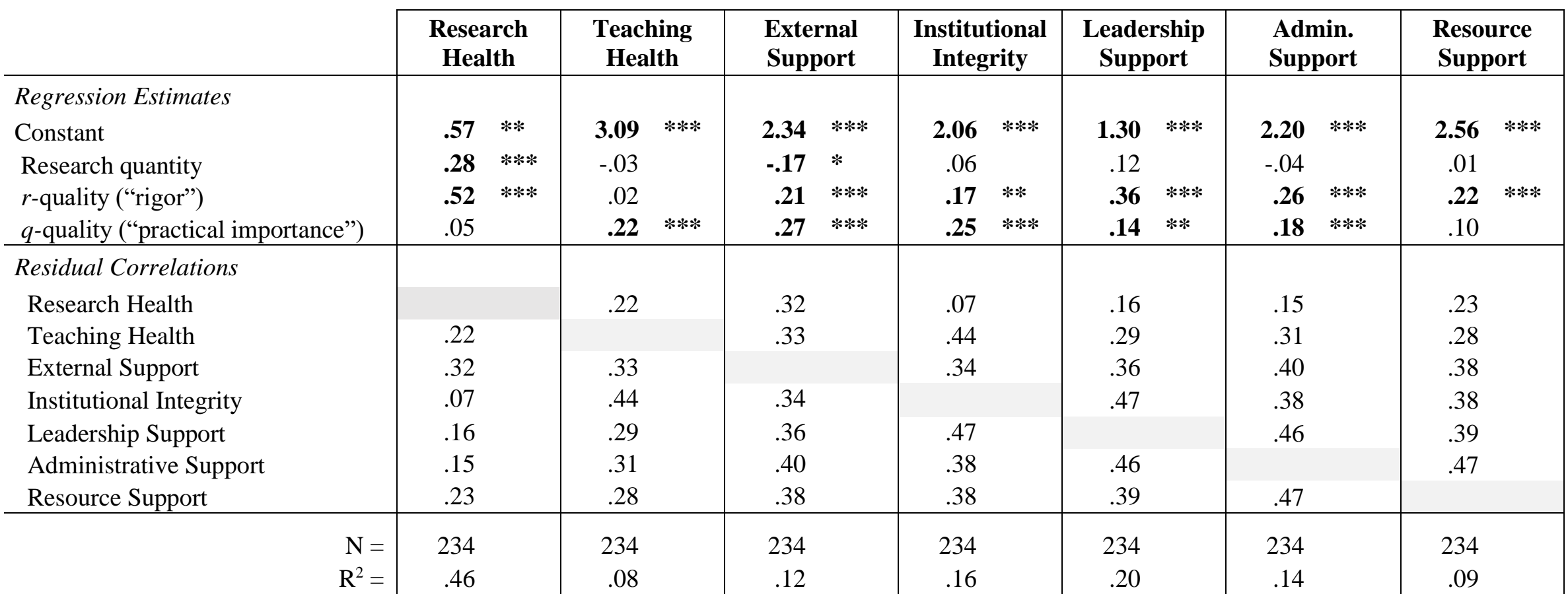

$* p<.10 ; * * p<.05 ; * * * p<.01$. All $p$-values are two-sided.

$\dagger$ The first four rows depict the parameter estimates from our multivariate regression. The subsequent seven rows depict the correlations obtained from the residual correlation matrix. We rely on a multivariate regression because it allows us to jointly estimate the seven models as one regression system while accounting for error correlations. Multivariate regression is a special case of Zellner's seemingly unrelated regression with identical regressors across equations, in which case the SUR estimator simplifies to OLS in each equation (Pindyck and Rubinfeld 1997). Yet, because it is a joint estimator, the multivariate regression also estimates between-equation error correlations, allowing us to efficiently test coefficients across equations. 


\section{Table 5: Synthetic Role Models According to a School's Leading Research Task Optimization Goal}

Its faculty publishes strong dual impact contributions (e.g., Guadagni and Little 1983). Therefore, the relevance of faculty

SRM-Q:

Stimulate q-quality research to non-academics is greatly appreciated. This school values thought leadership in a substantive area. Faculty in these schools are typically leading expert witnesses, leading consultants, or (co-)founders of firms which are spin-offs of their academic work, in addition to their professor duties. Faculty's work shows high creativity and is recognized by awards from academic and non-academic endorsement institutions that recognize relevance (e.g., INFORMS Buck Weaver Award). In faculty assessment committees, committee members evaluate and appreciate "translational" publications (e.g., books or publications in practitioner-oriented outlets). P\&T decisions are extremely selective. There are no bonuses because outstanding performance is expected as a regular duty. While faculty have very high academic freedom, it is bounded by very strong professional expectations.

\begin{tabular}{l}
\hline SRM-R: \\
Stimulate \\
r-quality
\end{tabular}

This school almost exclusively values publications in journals that are recognized as leading in their respective fields. For tenure, only publications in these journals count. Highly cited papers are seen as "home runs" if they exemplify an original contribution (e.g., Bass 1969). Best paper awards from top journals and awards from leading endorsement institutions are "hard currency". Editorship of leading journals is considered strong service to the department and to the school and often receives teaching credit. Faculty are expected to take leadership positions and participate in steering committees in academic cohesion institutions (e.g., ACR, INFORMS). Committees that assess faculty go beyond counting the number of top journal publications and read the work of the candidate in detail. Faculty receive salary increases and promotions as their scientific prestige increases among the leading scholarly international community. Academic freedom is a fundamental reward. Receiving tenure is the ticket for such intellectual freedom but is not given to many in a selective promotion and tenure system. Reference letters are typically asked from highly prolific scholars in top journals who are completely independent from the candidate (no coauthors, no supervisor-student relationships, etc.)

This school frequently measures the number of publications of its faculty, typically by ISI-quantile or by standards in the field (e.g., A journals). P\&T decisions are not very selective, with promotion and tenure typically occurring as soon as a

\section{SRM-Qty:}

Stimulate research quantity candidate crosses a clear quantity cutoff. The metric counting system is very well developed into a protocol and is very clearly monitored by committees, such as P\&T committees. This monitoring system is externally audited by specialized institutions or external review committees often composed of leading international scholars. Faculty are expected to join academic cohesion institutions, which are valued because they enrich faculty's collaboration networks. Faculty get dedicated research time that is sufficient to do enough research. Faculty are assigned a personal research budget that is sufficient to execute their research. Faculty are rewarded in terms of career progression according to the amount of research that they publish. Faculty get a salary that is based on research output. The teaching load varies according to publication volume. 


\section{REFERENCES}

Agarwal, Rajshree, and Atsushi Ohyama (2013), "Industry or Academia, Basic or Applied? Career Choices and Earnings Trajectories of Scientists," Management Science, 59(4), 950970.

Aguinis, Herman, Chailin Cummings, Ravi S. Ramani, and Thomas S. Cummings (2020), “'An A is an A': The New Bottom Line for Valuing Academic Research," Academy of Management Perspectives, 34(1), 135-154.

Ahuja, Gautam, and Sai Yayavaram (2011), "Perspective - Explaining Influence Rents: The Case for an Institutions-Based View of Strategy," Organization Science, 22(6), 1631-1652.

Akerlof, George A. (2020), "Sins of Omission and the Practice of Economics," Journal of Economic Literature, 58(2), 405-18.

AMA Task Force on the Development of Marketing Thought (1988), "Developing, Disseminating, and Utilizing Marketing Knowledge," Journal of Marketing, 1-25.

Amabile, Teresa M. (1998), "How to Kill Creativity," Harvard Business Review, Sep/Oct, 77-87. American Library Association (2000), Information Literacy Competency Standards for Higher Education. Chicago, IL: Association of College \& Research Libraries.

Armstrong, J. Scott, and Tad Sperry (1994), "The Ombudsman: Business School Prestige Research versus Teaching," Interfaces, 24(2), 13-43.

Bagozzi, Richard P. and Youjae Yi (1988), "On the Evaluation of Structural Equation Models," Journal of the Academy of Marketing Science, 16 (1), 74-94.

Bartunek, Jean M. (2007), "Academic-Practitioner Collaboration Need Not Require Joint or Relevant Research: Toward a Relational Scholarship of Integration," The Academy of Management Journal, 50(6), 1323-1333.

Bass, Frank M. (1969), “A New Product Growth for Model Consumer Durables,” Management Science, 15(5), 215-227.

Baumeister, Roy F., and Julie Juola Exline (1999), "Virtue, Personality, and Social Relations: Self-Control as the Moral Muscle," Journal of Personality, 67(6), 1165-1194.

Bedeian, Arthur G., Shannon G. Taylor, and Alan N. Miller (2010), "Management Science on the Credibility Bubble: Cardinal Sins and Various Misdemeanors," Academy of Management Learning \& Education, 9(4), 715-725.

Benbasat, Izak and Ron W. Zmud (1999), "Empirical Research in Information Systems: The Practice of Relevance," MIS Quarterly, 23(1), 3-16.

Bennis, Warren G. and Jim O'Toole (2005), "How Business Schools Have Lost Their Way," Harvard Business Review, 83(5), 96-104.

Besancenot, Damien, Joao Ricardo Faria, and Radu Vranceanu (2009), "Why Business Schools Do So Much Research: A Signaling Explanation," Research Policy, 38, 1093-1101.

Bettis, Richard A. (2012), "The Search for Asterisks: Compromised Statistical Tests and Flawed Theories," Strategic Management Journal, 33(1), 108-113.

Bradlow, Eric T. (2008), "Editorial: Enticing and Publishing the Home Run Paper," Marketing Science, 27(1), 4-6.

Breusch, Trevor S. and Adrian R. Pagan (1980), "The Lagrange Multiplier Test and its Application to Model Specification in Econometrics", Review of Economic Studies, 47(1), 239-253. 
Burroughs, James E., Darren W. Dahl, C. Page Moreau, Amitava Chattopadhyay, and Gerald J. Gorn (2011), "Facilitating and Rewarding Creativity During New Product Development," Journal of Marketing, 75(4), 53-67.

Clotfelter, Charles, Elizabeth Glennie, Helen Ladd, and Jacob Vigdor (2008), "Would Higher Salaries Keep Teachers in High-Poverty Schools? Evidence from a Policy Intervention in North Carolina," Journal of Public Economics, 92(5-6), 1352-1370.

Cohen, Patricia, Jacob Cohen, Jeanne Teresi, Margaret March, and C. Noemi Velez (1990), "Problems in the Measurement of Latent Variables in Structural Equations Causal Models," Applied Psychological Measurement, 14(2), 183-196.

Cole, Stephen, and Jonathan R. Cole (1967), "Scientific Output and Recognition: A Study in the Operation of the Reward System in Science," American Sociological Review, 32, 377-390.

Daft, Richard L., and Arie Y. Lewin (1990), "Can Organization Studies Begin to Break out of the Normal Science Straitjacket? An Editorial Essay," Organization Science, 1(1), 1-9.

Edwards, Jeffrey R. (2011), "The Fallacy of Formative Measurement," Organizational Research Methods, 14(2), 370-388.

Ellison, Glenn (2002), "Evolving Standards for Academic Publishing: A q-r Theory," Journal of Political Economy, 110(5), 994-1034.

Engeler, Isabelle and Priya Raghubir (2018), "Decomposing the Cross-Sex Misprediction Bias of Dating Behaviors: Do Men Overestimate or Women Underreport their Sexual Intentions?," Journal of Personality and Social Psychology, 114(1), 95-109.

Fornell, Claes and David F. Larcker (1981), "Evaluating Structural Equation Models with Unobservable Variables and Measurement Error," Journal of Marketing Research, 17 (Feb.), 39-50.

Fournier, Susan (1998), "Consumers and Their Brands: Developing Relationship Theory in Consumer Research," Journal of Consumer Research, 24(4), 343-373.

Franceschet, Massimo (2011), "Collaboration in Computer Science: A Network Science Approach," Journal of the American Society for Information Science and Technology, 62(10), 1992-2012.

Frey, Bruno S. and Jana Gallus (2017), “Towards an Economics of Awards,” Journal of Economic Surveys, 31(1), 190-200.

Frey, Bruno S. and Reto Jegen (2001), "Motivation Crowding Theory," Journal of Economic Surveys, 15(5), 589-611.

Gerbing, David W. and James C. Anderson (1988), “An Updated Paradigm for Scale Development Incorporating Unidimensionality and its Assessment," Journal of Marketing Research, 25(2), 186-192.

Gomez-Mejia, Luis R. and David B. Balkin (1992), "Determinants of Faculty Pay: An Agency Theory Perspective,” The Academy of Management Journal, 35(5), 921-955.

Guadagni, Peter M., and John DC Little (1983), "A Logit Model of Brand Choice Calibrated on Scanner Data, Marketing Science, 2(3), 203-238.

Guadagnoli, Edward and Wayne F. Velicer (1988), "Relation of Sample Size to the Stability of Component Patterns," Psychological Bulletin, 103(2), 265-275.

Gulati, Ranjay (2007), “Tent Poles, Tribalism, and Boundary Spanning: The Rigor-Relevance Debate in Management Research,” The Academy of Management Journal, 50(4), 775-782.

Hair, Joseph F., Jr., William C. Black, Barry J. Babin, and Rolph E. Anderson (2014). Multivariate Data Analysis, Seventh Ed. Harlow, Essex, UK: Pearson Education Limited. 
Hattie, John and H.W. Marsh (1996), "The Relationship Between Research and Teaching: A Meta-Analysis," Review of Educational Research, 66(4), 507-542.

Heckman, James J. and Sidharth Moktan (2020), "Publishing and Promotion in Economics: The Tyranny of the Top Five," Journal of Economic Literature, 58(2), 419-470.

Holmstrom, Bengt and Paul Milgrom (1991), "Multitask Principal-Agent Analyses: Incentive Contracts, Asset Ownership, and Job Design," Journal of Law, Economics \& Organization, 7, 24-52.

Homburg, Christian, Martin Klarmann, Martin Reimann and Oliver Schilke (2012), "What Drives Key Informant Accuracy?,” Journal of Marketing Research, 49(4), 594-608.

Hoy, Wayne K., C. John Tarter, and Robert B. Kottkamp (1991), Open Schools/Healthy Schools: Measuring Organizational Climate. Beverly Hills, CA: Sage.

Hoy, Wayne K., and Anita E. Woolfolk (1993), "Teachers' Sense of Efficacy and the Organizational Health of Schools," The Elementary School Journal, 93(4), 355-372.

Jaworski, Bernard J. (2011), “On Managerial Relevance,” Journal of Marketing, 75(4), 211-224. John, Leslie K., George Loewenstein, and Drazen Prelec (2012), "Measuring the Prevalence of Questionable Research Practices with Incentives for Truth Telling," Psychological Science, 23(5), 524-532.

Joseph, Kissan and Alex Thevaranjan (1998), "Monitoring and Incentives in Sales Organizations: An Agency-Theoretic Perspective," Marketing Science, 17(2), 107-123.

Kaplan, Robert S. (2011), "Accounting Scholarship that Advances Professional Knowledge and Practice," The Accounting Review, 86(2), 367-383.

Lehmann, Don R., Leigh McAlister, and Richard Staelin (2011), "Sophistication in Research in Marketing," Journal of Marketing, 75(4), 155-165.

Lightfield, E. Timothy (1971), "Output and Recognition of Sociologists," The American Sociologist, 6(2), 128-133.

Lilien, Gary L. (2011), "Bridging the Academic-Practitioner Divide in Marketing Decision Models," Journal of Marketing, 75(4), 196-210.

MacInnis, Deborah J., (2011), "A Framework for Conceptual Contributions in Marketing," Journal of Marketing, 75(July), 136-154.

Mael, Fred, and Blake E. Ashforth (1992), "Alumni and their Alma Mater: A Partial Test of the Reformulated Model of Organizational Identification," Journal of Organizational Behavior, 13(2), 103-123.

McFarlin, Dean B., Roy F. Baumeister, and Jim Blascovich (1984), “On Knowing When to Quit: Task Failure, Self-Esteem, Advice, and Nonproductive Persistence,” Journal of Personality, 52(2), 138-155.

Merton, Robert K., and Patricia L. Kendall (1946), “The Focused Interview,” American Journal of Sociology, 51(6), 541-557.

Miles, Matthew B. (1965), "Planned Change and Organizational Health: Figure and Ground," in Change Processes in the Public Schools, Richard O. Carlson, Art Gallaher, Jr., Matthew B. Miles, Roland J. Pellegrin, and Everett M. Rogers, eds. Eugene, OR: University of Oregon.

Mitra, Debanjan and Peter N. Golder (2008), "Does Academic Research Help or Hurt MBA Programs?," Journal of Marketing, 72(5), 31-49.

Nielson, Daniel L. and Michael J. Tierney (2003), "Delegation to International Organizations: Agency Theory and World Bank Environmental Reform," International Organization, 57(2), 241-276. 
Nosek, Brian A., George Alter, George C. Banks, Denny Borsboom, Sara D. Bowman, Steven J. Breckler, Stuart Buck et al. (2015), "Promoting an Open Research Culture," Science, 348(6242), 1422-1425.

Parsons, Talcott (1951). The Social System. Glecoe, IL: Free Press.

Pepper, Alexander and Julie Gore (2015), "Behavioral Agency Theory: New Foundations for

Theorizing about Executive Compensation," Journal of Management, 41(4), 1045-1068.

Perry, David M. (2020), "For Some Colleges, Missing the Fall Semester May Be Just the Tip of the Iceberg," CNN, (April 15), [available: at

https://edition.cnn.com/2020/04/15/opinions/colleges-and-higher-ed-covid-19-changes-

perry/index.html].

Pfeffer, Jeffrey and Christina T. Fong (2002), "The End of Business Schools? Less Success than

Meets the Eye," Academy of Management Learning \& Education, 1(1), 78-95.

Podsakoff, Phillip M., Scott B. MacKenzie, Jeong-Yeon Lee and Nathan P. Podsakoff (2003),

"Common Method Biases in Behavioral Research: A Critical Review of the Literature and

Recommended Remedies," Journal of Applied Psychology, 88(5), 879-903.

Posner, Richard A. (2010), "From the New Institutional Economics to Organization Economics:

With Applications to Corporate Governance, Government Agencies, and Legal

Institutions," Journal of Institutional Economics, 6(1), 1-37.

Pindyck, Robert S., and Daniel L. Rubinfeld (1997). Econometric Models and Economic

Forecasts, $4^{\text {th }}$ ed. Irwin, NY: McGraw-Hill.

Ray, Debraj (2006), "Aspirations, Poverty, and Economic Change," in What Have We Learnt

About Poverty, Abhijit V. Banerjee, Roland Bénabou, and Dilip Mookherjee, ed. Oxford:

Oxford University Press, 409-422.

Reibstein, David J., George Day, and Jerry Wind (2009), “Guest Editorial: Is Marketing

Academia Losing Its Way?," Journal of Marketing, 73(4), 1-3.

Rindfleisch, Aric, Alan J. Malter, Shankar Ganesan and Christine Moorman (2008), "Cross-

Sectional versus Longitudinal Survey Research: Concepts, Findings, and Guidelines,"

Journal of Marketing Research, 45(3), 261-279.

Roberts, John (2010), "Designing Incentives in Organizations," Journal of Institutional Economics, 6(1), 125-132.

Roberts, John H., Ujwal Kayande, and Stefan Stremersch (2014), "From Academic Research to Marketing Practice: Exploring the Marketing Science Value Chain," International Journal of Research in Marketing, 31, 127-140.

Rosemann, Michael, and Iris Vessey (2008), "Toward Improving the Relevance of Information Systems Research to Practice: The Role of Applicability Checks," MIS Quarterly, 32(1), 122.

RRBM, Co-founders of (2017). A Vision for Responsible Research in Business and Management: Striving for Useful and Credible Knowledge. Position Paper, accessible: www.rrbm.network (rev 2020).

Rynes, Sara L., Jean M. Bartunek, and Richard L. Daft (2001), "Across the Great Divide:

Knowledge Creation and Transfer Between Practitioners and Academics," The Academy of Management Journal, 44(2), 340-355.

Rynes, Sara L., Tamara L. Giluk, and Kenneth G. Brown (2007), “The Very Separate Worlds of Academic and Practitioner Periodicals in Human Resource Management: Implications for Evidence-Based Management," The Academy of Management Journal, 50(5), 987-1008. 
Sadoski, Mark, Ernest T. Goetz, and Joyce B. Fritz (1993), "Impact of Concreteness on Comprehensibility, Interest, and Memory for Text: Implications for Dual Coding Theory and Text Design," Journal of Educational Psychology, 85(2), 291-304.

Shapiro, Debra L., Bradley L. Kirkman, and Hugh G. Courtney (2007), "Perceived Causes and Solutions of the Translation Problem in Management Research," The Academy of Management Journal, 50(2), 249-266.

Shapiro, Susan (2005), "Agency Theory," Annual Review of Sociology, 31, 263-284.

Sharma, Anurag (1997), "Professional as Agent: Knowledge Asymmetry in Agency Exchange," Academy of Management Review, 22(3), 758-798.

Shugan, Steven M. (2003), "Editorial: Defining Interesting Research Problems," Marketing Science, 22(1), 1-15.

Shugan, Steven M. and Debanjan Mitra (2009), "Metrics - When and Why Nonaveraging Statistics Work," Management Science, 55(1), 4-15.

Simonsohn, Uri, Niklas Karlsson, George Loewenstein, and Dan Ariely (2008), "The Tree of

Experience in the Forest of Information: Overweighing Experienced Relative to Observed Information," Games and Economic Behavior, 62(1), 263-286.

Stewart, David W. (2020), "Creativity and Publication in Marketing," AMS Review, 10, 65-72. Stremersch, Stefan, Isabel Verniers, and Peter C. Verhoef (2007), "The Quest for Citations:

Drivers of Article Impact," Journal of Marketing, 71(3), 171-193.

Stremersch, Stefan, Nuno Camacho, Sofie Vanneste, and Isabel Verniers (2015), "Unraveling Scientific Impact: Citation Types in Marketing Journals," International Journal of Research in Marketing, 32(1), 64-77.

Thaler, Richard H. (2010), "From Homo Economicus to Homo Sapiens," Journal of Economic Perspectives, 14(1), 133-141.

Thompson, Craig J., William B. Locander, and Howard R. Pollio (1989), "Putting Consumer

Experience Back into Consumer Research: The Philosophy and Method of ExistentialPhenomenology," Journal of Consumer Research, 16(2), 133-146.

Trieschmann, James S., Alan R. Dennis, Gregory B. Northcraft, and Albert W. Niemi, Jr. (2000), "Serving Constituencies in Business Schools: MBA Program versus Research Performance," The Academy of Management Journal, 43(6), 1130-1141.

Trope, Yaacov, and Nira Liberman (2010), "Construal-Level Theory of Psychological Distance," Psychological Review, 117(2), 440-463.

Tushman, Michael and Charles A. O'Reilly III (2007), "Research and Relevance: Implications of Pasteur's Quadrant for Doctoral Programs and Faculty Development," The Academy of Management Journal, 50(4), 769-774.

Vermeulen, Freek (2005), "On Rigor and Relevance: Fostering Dialectic Progress in Management Research," The Academy of Management Journal, 48(6), 978-982.

Vermeulen, Freek (2007), "I Shall Not Remain Insignificant: Adding a Second Loop to Matter More," The Academy of Management Journal, 50(4), 754-761.

Williams, Lynne J. and Hervé Abdi (2010), "Fisher's Least Significant Difference (LSD) Test," in Encyclopedia of Research Design, Neil J. Salkind, ed. Thousand Oaks, CA: Sage. 